TOMASZ GAEUSZKA OP

Dominikański Instytut Historyczny Uniwersytet Papieski Jana Pawła II w Krakowie

\title{
MIKOŁAJA DUTHOROWA ERROR CONDEMNATUS AB ECCLESIA. DOMINIKANIE POLSCY WOBEC HEREZJI I NOWYCH NURTÓW POBOŻNOŚCI W PIERWSZEJ POŁOWIE XIV W.*
}

W 2010 r. krakowski historyk Maciej Zdanek przedstawił ważne studium, w którym krótko podsumował dotychczasowe badania nad dominikanami polskimi w XIV w. oraz ogłosił edycję najstarszych zachowanych akt polskiej kapituły prowincjalnej z 1338 r. ${ }^{1}$ Badacz ten sformułował również dwa fundamentalne postulaty: wyszukania i udostępnienia nowych źródeł, a równocześnie gruntowanej i wieloaspektowej analizy ich treści. W odpowiedzi na ostatni z postulatów chciałbym w niniejszym opracowaniu zatrzymać się przy jednym niewielkim fragmencie wspomnianych akt z 1338 r., w którym „mamy tylko - jak pisał wydawca - szczątkową informację o jakiejś karalnej niesubordynacji zakonnika z Gryfii [- - ] oraz nakaz karania więzieniem wszystkich prowadzących vitam singularem, niezgodnie $\mathrm{z}$ "dobrymi obyczajami»"2. Okazuje się jednak, że analiza tego fragmentu przynosi szereg nowych, często rewelacyjnych danych dotyczących zarówno dziejów kultury umysłowej dominikanów, nowych ruchów religijnych, jak i historii inkwizycji papieskiej w Polsce.

Akta polskiej kapituły prowincjalnej z $1338 \mathrm{r}$. zachowały się w formie mocno uszkodzonej pergaminowej karty o wymiarach $273 \times 192 \mathrm{~mm}$.

\footnotetext{
* Praca została napisana w ramach projektu nr 11 H 120169 81, finansowanego ze środków przyznanych przez Narodowy Program Rozwoju Humanistyki.

${ }^{1}$ Zob. M. Zdanek, Fragment akt kapituły prowincjalnej dominikanów polskich z 1338 roku, RH 76, 2010, s. 263-276, edycja akt: 270-272 (dalej cyt: ed.). Dziękuję Krzysztofowi Ożogowi i Maciejowi Zdankowi za życzliwą pomoc w trakcie przygotowania tekstu.

${ }^{2}$ Ibidem, s. 268-269.
} 
Przecięcia marginesów, liczne wytarcia i zabrudzenia oraz drobne kursywne pismo gotyckie poważnie utrudniają lekturę tego źródła ${ }^{3}$.Zachowana karta stanowiła końcową część akt i obejmowała pięć części, właściwych dla formularza średniowiecznych dominikańskich akt kapituł prowincjalnych ${ }^{4}$ : zwolnienie z urzędu przeorskiego i powołanie wikariuszy oraz wizytatorów (absolutiones); pokuty dla zakonników, którzy poważnie naruszyli zasady życia dominikańskiego (pœnitentic); zalecenia odnoszące się do dyscypliny zakonnej i życia w prowincji (ordinationes); obligacje mszalne za żywych i zmarłych dobrodziejów zakonu i prowincji (suffragia vivorum et defunctorum); asygnaty braci na kapituły generalne oraz wyznaczenie miejsca i daty kolejnej kapituły prowincjalnej (epilogus). Fragment, który poddam analizie, znajduje się w części poświęconej pokutom ${ }^{5}$.Zanim jednak go przytoczę, wypada mi wspomnieć o zmianach, jakie wprowadziłem w tekst edycji przygotowanej przez M.Zdanka. W wyniku bowiem ponownej analizy paleograficznej udało się rozstrzygnąć niektóre wątpliwości sygnalizowane przez samego wydawcę oraz zaproponować kilka nowych odczytów.

[.....frat]er ${ }^{\mathrm{a}}$ Nicolaus Duthorow in conuentu Gripswal[diensi] errorem condemnatum ab Ecclesia non sanctorum patrum decretis -immittendo ${ }^{b}-1$, sed pocius sue prudencie false immitte $[$ ndo.

populo $\mathrm{p}[$...............

[.......... fuisse passum ${ }^{\mathrm{e}}$ non solum secundum humanam, sed etiam ${ }^{\mathrm{f}}$ secundum diuinam naturam, ut sufficienter ${ }^{g}$ contra eum est probatum, ipsum omni predicacione ac omnibus graciis Ordinis priuamus. Et nisi ${ }^{\mathrm{h}}$ publice dictum errorem $\mathrm{r}$ [ evocet.........]

[.......... Ecclesia, que ${ }^{j}$ cunctorum fidelium est mater et magistra, ex tunc sentenciamus eum ad carcerem perpetuum. Volumus, notificamus et

${ }^{3}$ Pełny opis kodykologiczny akt z 1338 r. zob. ibidem, s. 265-266.

${ }^{4}$ Więcej na temat formularza dominikańskich akt kapituł zob. T. Gałuszka, Fragmenty czternastowiecznych akt kapituł prowincjalnych dominikanów polskich $w$ zbiorach Bayerische Staatsbibliothek w Monachium. Kapituła prowincjalna w Opatowcu w 1384 roku, St. Źr 51, 2013, s. 105-120.

${ }^{5}$ Zob.M.Zdanek, op. cit., s. 270.

a braked.

${ }^{\mathrm{b}}$ succumbendo ed.

c tum ed.

d pto ed.

e possum ed.

$\mathrm{f}$ in ed.

g sufficieretur ed.

$\mathrm{h}$ in ed.

i braked.

j qua ed. 
imponimus inquisitoribus sub precepto, quod ubicumque tales, sic periculosum et damnab[ile ${ }^{\mathrm{k}}$............]

[.........] singularem vitam ducentes, aut contra bonos mores agentes reperiunt ${ }^{1}$, eos incarcerandi liberam habeant potestatem.

Przytoczony fragment akt polskiej kapituły z 1338 r. składa się z dwóch części: pokuty (pœenitentia) i krótkiego zarządzenia (ordinatio). Z treści pokuty dowiadujemy się, że brat Mikołaj Duthorow rozpowszechniał w konwencie w Gryfii tezy teologiczne, które zostały uznane przez kapitułę prowincjalną za error condemnatus ab Ecclesia; przewinienie oskarżonego było na tyle poważne, że nałożono na niego szereg kar, z groźbą dożywotniego więzienia włącznie. Zarządzenie natomiast skierowane było do miejscowych inkwizytorów. Mieli oni ścigać osoby, które prowadziły życie niezgodne z prawem kościelnym i dobrymi zwyczajami.

Nie ulega wątpliwości, że każda z tych dwóch części rodzi szereg pytań i wątpliwości. W pierwszej kolejności, przy pobieżnej lekturze nie sposób uchwycić istoty i genezy błędnych nauk brata Mikołaja. Nie wiemy również, kim były osoby prowadzące vitam singularem. Ponadto komentarza wymaga sam fakt wystosowania przez dominikańską kapitułę zarządzenia do inkwizytorów papieskich. Trzeba także zastanowić się, czy obie części analizowanego fragmentu akt należy interpretować w ścisłym powiązaniu, jako świadectwo funkcjonowania jednego, nielegalnego ruchu religijnego, którego przedstawicielem był Mikołaj Duthorow, czy też mamy do czynienia z dwoma różnymi problemami, których częścią wspólną jest wyłącznie kwestia ich wątpliwej ortodoksyjności.

II

Postać głównego bohatera pœnitentiø - dominikanina Mikołaja Duthorowa jest dość zagadkowa. Nie udało się dotąd odnaleźć jakichkolwiek wzmianek na jego temat w źródłach polskich ani obcych. Dysponujemy więc - jak dotąd - tylko informacjami z akt prowincjalnych z $1338 \mathrm{r}$. Ponieważ kapituła zakazała mu pełnienia posługi kaznodziejskiej, Mikołaj musiał być kapłanem i posiadać odpowiednie przygotowanie teologiczne $^{6}$. Nie znamy miejsca jego asygnaty zakonnej. Jednak z faktu wygłoszenia swoich poglądów w klasztorze w Gryfii (niem. Greifswald)

k braked.

${ }^{1}$ repereriunt $\mathrm{rkp}$. | repererunt ed.

${ }^{6}$ Zob. Constitutiones antique Ordinis Fratrum Prcedicatorum, w: De oudste constituties van de dominicanen, wyd. A. H. Thomas, Leuven 1965, dist. 2, cap. 32-33, s. 364-365. 
możemy wnioskować, że należał do tej właśnie wspólnoty zakonnej ${ }^{7}$. Mimo że konwent ten znajdował się w znacznej odległości od takich ośrodków jak Kraków czy Wrocław, niewątpliwie zajmował istotne miejsce na średniowiecznej mapie polskiej prowincji. Tutaj m.in. urzędował wikariusz kontraty kaszubskiej, który w imieniu polskiego prowincjała nadzorował klasztory w Gryfii, Kamieniu Pomorskim, Słupsku, Pozdawilku i Ińsku. Dzięki ostatnim badaniom nad odkrytymi w Monachium aktami kapituły prowincjalnej z 1384 r. wiemy, że w Gryfii już w XIV w. obok szkoły konwentualnej działało również partykularne studium filozofii (naturarum), a być może również studia sztuk (artium) i teologii (theologice $)^{8}$. Z kolei w połowie XV w. tamtejszy konwent posiadał drugie w polskiej prowincji dominikańskie studium generale ${ }^{9}$. Mikołaj Duthorow miał zatem realne możliwości, by zetknąć się z różnymi toczącymi się ówcześnie debatami teologicznymi i nowymi nurtami dewocyjnymi. Najlepszym potwierdzeniem tego przypuszczenia są - jak zobaczymy dalej głoszone przez niego poglądy.

Akta kapituły, wspominając o sprawie Mikołaja, precyzyjnie zaznaczyły, że gryfijski dominikanin nie był heretykiem, ani nie wyznawał poglądów heretyckich sensu stricto, lecz „,jedynie” głosił i rozpowszechniał treści niezgodne z oficjalną nauką Kościoła (error condemnatus ab Ecclesia). Odnajdujemy tutaj echa powszechnie znanego, pochodzącego od Augustyna rozróżnienia na error, czyli błąd w intelekcie, i høeresis, czyli świadome i uporczywe trwanie w błędzie ${ }^{10}$. Dystynkcja ta w XIV w. znana była głównie za pośrednictwem Dekretu Gracjana, a w środowisku dominikańskim również za sprawą św. Tomasza z Akwinu i jego Summy teologii ${ }^{11}$.

${ }^{7}$ Konwent w Gryfii został ufundowany ok. 1261-1264 r. Dotychczas nie powstało żadne osobne studium na temat tego klasztoru, zob. T. Pyl, Geschichte der Greifswalder Kirchen und Klöster, sowie ihrer Denkmäler nebst einer Einleitung vom Ursprunge der Stadt Greifswald, t. 1, Greifswald 1885, s. 216-221; J. Kłoczowski, Dominikanie polscy nad Battykiem w XIII wieku, w: idem, Polska prowincja dominikańska w średniowieczu i Rzeczypospolitej Obojga (Wielu) Narodów, Poznań 2008, s. 112,123-125.

${ }^{8}$ Zob. T. Gałuszka, Szkolnictwo konwentualne i partykularne w strukturach polskiej prowincji dominikanów XIV stulecia. Nowe ujęcie w świetle nowych źródeł, RH 78, 2012, s. 204-205.

${ }_{9}$ Zob. K. Kaczmarek, Szkoły i studia dominikanów polskich $w$ średniowieczu, Poznań 2005, s. 367-373.

${ }^{10}$ Zob. Augustinus, Epistola XLIII, PL, t. 33, c. 1, n. 1, kol. 160; idem, De horesibus, wyd. R. Vander Plætse, C. Beukers, Turnhout 1969, præf. 7, s. 289, Corpus Christianorum Series Latina, t. 44. Zob. także J. D. Mann, William of Ockham, Juan de Segovia and Heretical Pertinacity, „Mediæval Studies” 56, 1994, s. 67-88; P. Kras, Ad abolendam diversarum hoeresium pravitatem. System inkwizycyjny w średniowiecznej Europie, Lublin 2006, s. 59-60.

${ }^{11}$ Zob. Decretum Gratiani, w: Corpus Iuris Canonici, t. 1, wyd. E. Friedberg, Leipzig 1879, Pars II, C. XXIV, q. 3, c. 29, kol. 998; Thomas de Aquino, Summa theologioe, w: Sancti Thomce Aquinatis Opera omnia iussu impensaque Leonis XIII P. M. edita (dalej: Editio Leonina), t. 8, Romae 1895, Pars II ${ }^{a}-I^{æ}$, q. 11, a. 2, ad 3, s. 99a. Zob. także: „Ad septimum dicen- 
Podjęcie przez polskich dominikanów sprawy Mikołaja możemy uznać za naturalną realizację zarządzeń zakonu. Od roku 1328 r. bowiem wszystkie kapituły prowincjalne zakonu zostały zobowiązane do karania tych braci, którzy w trakcie działalność kaznodziejskiej rozpowszechniali nauki błędne i kontrowersyjne ${ }^{12}$.

Polscy dominikanie podeszli do interesującej nas sprawy z całą powagą i wyjątkową surowością. Stwierdzono wprost, że działanie Mikołaja było w pełni świadome, co zostało podkreślone w tekście akt za pomocą oryginalnego terminu „fałszywa roztropność” (prudentia falsa). Już teraz zaznaczmy, że prudentia falsa jest czymś zgoła innym niż imprudentia, czyli wynikający z niedostatków intelektualnych lub ograniczonej świadomości brak roztropności. Wyrażenie to zostało wprowadzone po raz pierwszy przez Tomasza z Akwinu w Summie teologii w kontekście rozważań nad cnotą roztropności. Akwinata wyróżnił jej trzy rodzaje: roztropność fałszywą (prudentia falsa), roztropność prawdziwą niedoskonałą (prudentia vera et imperfecta) i roztropność prawdziwą doskonałą (prudentia vera et perfecta) ${ }^{13}$. Synonimami „fałszywej roztropności” były według Tomasza m.in. biblijna prudentia carnis, która została wspomniana w Liście do Rzymian (Rom 8,6), prudentia mundi, o której pisze Grzegorz Wielki ${ }^{14}$, czy wreszcie arystotelesowska astutia, tj. przebiegłość w złym ${ }^{15}$. Obrazem zaś człowieka „fałszywie roztropnego" par excellence miałby być - jak podaje autor Summy teologii „dobry złoczyńca, np. złodziej, ponieważ poprzez podobieństwo do dob-

dum, quod quatuor videntur ad defectum cognitionis pertinere; scilicet nescientia, ignorantia, error et hæresis", Thomas de Aquino, De malo, w: Editio Leonina, t. 23, RomaParis 1982, q. 8, a. 1, ad 7, s. 195, lin. 206-408. Na temat Tomaszowego rozumienia herezji zob. Š. M. Filip, „Takový člověk je převrácený” Sv. Tomáš A kvinský o (ne)tolerování heretikٌ̊, „Salve. Revue pro teologii, duchovní život” 2011, 4, s. 57-98.

${ }_{12}$ Zob. „Cum ex eo quod aliqui in predicacionibus ad populum conantur tractare quedam subtilia, que non solum ad mores non proficiunt, quinimo facilius ducunt populum in errorem, precipit magister ordinis in virtute sancte obediencie de diffinitorum consilio et assensu, quod nullus de cetero presumat talia in suis sermonibus pertractare", Acta capitulorum generalium ordinis Proedicatorum, t. 1-3, wyd. B. M. Reichert, Romæ-Stuttgardiæ 1898-1900, Monumenta Ordinis Fratrum Prædicatorum historica, t. 3-8 (dalej: MOPH), tu: t. 4, s. 180. Warto zauważyć, że w XV w. jednym z elementów obrad kapituły prowincjalnej była debata teologiczna, która miała za zadanie m.in. rozstrzygać zaistniałe wśród dominikanów spory doktrynalne, zob. M. Kowalczyk, Dysputa teologiczna u dominikanów w Warce w 1468 roku, ,Przegląd Tomistyczny” 9, 2003, s. 171-174.

${ }^{13}$ Zob. Thomas de Aquino, Summa theologice, Pars $\mathrm{II}^{\mathrm{a}}-\mathrm{II}^{\mathfrak{x}}$, q. 47, a. 13, resp, et ad 1, s. $361 \mathrm{a}-\mathrm{b}$.

${ }^{14}$ Zob. Gregorius Magnus, Moralia in Iob, PL, t. 75, lib. 10, c. 29, kol. 947, cyt. za: Thomas de Aquino, Summa theologioe, Pars $\mathrm{II}^{\mathrm{a}}-\mathrm{II}^{\text {æ }}$, q. 55 a. 3, ad 3, s. $400 \mathrm{~b}$.

${ }^{15}$ Aristoteles, Ethica Nicomachea, w: Aristoteles Latinus, t. 26/1-3, wyd. R. A. Gauthier, Turnhout 1973, VII, 7, 1141 b 14, cyt. za: Thomas de Aquino, Summa theologice, Pars II ${ }^{a}-I^{\circledR}$, q. 47, a. 13, ad 3, s. 361 b. 
rych ludzi jest on roztropny w stosowaniu dróg do celu, ale złego"16. Biorąc pod uwagę powyższe uwagi, przypisanie Mikołajowi prudentia falsa zdaje się wskazywać, że w opinii swoich współbraci oskarżony dominikanin musiał być człowiekiem inteligentnym, aczkolwiek źle wykorzystującym posiadaną wiedzę i umiejętności.

Nie dziwi zatem rodzaj sankcji, jaką kapituła prowincjalna nałożyła na Mikołaja.Zakazano mu głoszenia kazań oraz pozbawiono wszelkich przywilejów zakonnych. Został też zobowiązany do publicznego (publice) odwołania błędnych tez. W przeciwnym wypadku miał otrzymać jedną z najwyższych kar, jaką przewidywało dominikańskie prawo karne - wieczyste więzienie (carcer perpetuus) ${ }^{17}$. W średniowiecznym ustawodawstwie zakonnym kara wieczystego więzienia przewidziana była przede wszystkim dla brata popełniającego przestępstwo, za które w prawie świeckim groziła albo kara śmierci (pœna capitalis), albo kary dręczące (pœnœ afflictivœ), albo też pozostawiające ślady na ciele osoby nimi dotkniętej (pœnœ indelebiles). Dla polskiej prowincji w miarę kompletne dane na temat tego typu kar posiadamy dopiero dla drugiej połowy XV w. W latach 1451-1517 pokutę w postaci carcer perpetuus odbywało pięciu polskich dominikanów: dwóch z nich popełniło morderstwo, jeden - świętokradztwo, dwóch - liczne wykroczenia przeciwko dyscyplinie zakonnej.

Kapituła z 1338 r., ogłaszając swoją decyzję odnośnie do osoby Mikołaja, włączyła w tekst akt rozbudowaną definicję Kościoła - „Ecclesia, que cunctorum fidelium est mater et magistra”. Powyższe sformułowanie nie jest oryginalnym teologiczno-prawniczym pomysłem polskich dominikanów. Odnajdujemy je w konstytucji Soboru Laterańskiego IV: „Romana tenet ecclesia, quæ disponente Domino cunctorum fidelium mater est et magistra"18. Konstytucja ta, rozpoczynająca się od znaczących słów: „Damnamus et reprobamus" dotyczyła błędów teologicznych (errores) Joachima z Fiore ${ }^{19}$. Cysterski opat - zdaniem ojców soborowych - miał podważyć

${ }^{16}$ „Secundum similitudinem, sicut dicitur aliquis bonus latro. Hoc enim modo potest secundum similitudinem dici prudens latro qui convenientes vias adinvenit ad latrocinandum", Thomas de Aquino, Summa theologioe, Pars $\mathrm{II}^{\mathrm{a}}-\mathrm{II}^{\circledR}$, q. 47, a. 13, resp., s. 361a.

${ }_{17}$ Zob. T. Gałuszka, Kara więzienia w późnośredniowiecznej polityce penitencjarnej dominikanów polskich, KH 117, 2010, 4, s. 65-79.

${ }^{18}$ Sobór Laterański IV, konst. II, 2,9, w: Dokumenty Soborów Powszechnych, oprac. A. Baron, H. Pietras, t. 2, Kraków 2003, s. 230-231 (dalej: DSP, t. 2). Konstytucja ta została włączona do Kodeksu prawa kanonicznego, zob. Decretales Gregorii IX, w: Corpus Iuris Canonici, t. 2, wyd. E. Friedberg, Leipzig 1881, lib. I, tit. 1, c. 2, kol. 7. Na temat miejsca konstytucji Damnamus w czternastowiecznych dominikańskich sporach teologicznych, zob. I. Iribarren, Durandus of St Pourcain: A Dominican Theologian in the Shadow of Aquinas, Oxford 2006, s. 151-153.

${ }^{19} \mathrm{Na}$ temat Joachima z Fiore, zob. J. Grzeszczak, Joachim z Fiore: średniowieczny przy- 
autorytet Piotra Lombarda i oskarżać go o głoszenie następującej herezji: obok Ojca, Syna i Ducha Świętego występuje jeszcze czwarty element - ich Jedność. W konsekwencji - jak twierdził Joachim - Trójca (Trinitas) przemieniała się w Czwórcę (Quaternitas). Joachim tak bardzo chciał bronić klasycznej trynitologii, że podważył w ogóle ortodoksyjną naukę na temat jedności w Bogu. Jedność Trójcy w rozumieniu Joachima nie była realna i właściwa (vera et propria), a jedynie symboliczna była jednością wspólnoty ujmowanej analogicznie (quasi collectiva et similitudinaria $)^{20}$. W odpowiedzi na interpretację Joachima Sobór krótko i w sposób niepozostawiający żadnych wątpliwości przypomniał klasyczną trynitarną doktrynę Kościoła na temat różnicy w Osobach (distinctio in personis) i jedności w Ich naturze (unitas in natura) ${ }^{21}$. Fakt, że bracia z prowincji polskiej w trakcie badania prawowierności poglądów gryfijskiego dominikanina posiłkowali się tym właśnie orzeczeniem Kościoła, stanowi ważną informację dla zrozumienia kontrowersji wokół poglądów Mikołaja Duthorowa.

W omawianym fragmencie akt prowincjalnych przywołana została tylko jedna błędna teza Mikołaja: ,fuisse passum non solum secundum humanam, sed etiam secundum diuinam naturam". Dodajmy już teraz, że chodziło o zagadnienie teologicznej interpretacji cierpienia Chrystusa (Christus passus est). Nasz dominikanin miałby zatem głosić, że Chrystus cierpiał nie tylko w ludzkiej, ale również w swojej boskiej naturze. Jak wiadomo, podobne twierdzenia teologiczne odnajdujemy na początku kształtowania się chrześcijańskiej dogmatyki. Stąd też ich pojawienie się wśród czternastowiecznych dominikanów wymaga dokładniejszego naświetlenia.

Problem cierpienia Boga, lub raczej jego niecierpiętliwości (impassibilitas Dei), został definitywnie rozstrzygnięty i zdefiniowany już w pierwszych wiekach chrześcijaństwa. Stało się to przy okazji kontrowersji wokół dwóch herezji trynitarnych, mających swoje źródło w doktrynach modalistycznych (monarchicznych): w patrypasjonizmie ${ }^{22}$ i w jego późniejszej kontynuacji, sabelianizmie ${ }^{23}$. Wspomnę tylko, że chodziło o heterodoksyjne doktryny, których zwolennicy (m.in. Noetus ze Smyrny, Prakseasz, Sabeliusz)

czynek do teologii dziejów, Poznań 2006; idem, Dall'Età dello Spirito Santo al New Age: Gioacchino da Fiore nella nuova religiosità, Poznań 2008 (tam obszerna bibliografia).

${ }^{20}$ Zob. DSP, t. 2, s. 225-227.

${ }^{21}$ Zob. ibidem, s. 228-229.

${ }^{22}$ Zob. M. Sarot, Patripassianism, Theopaschitism and the Suffering of God. Some Historical and Systematic Considerations, ,Religious Studies” 26, 1990, 3, s. 363-375; Z. Krzyszowski, Patrypasjonizm, w: Encyklopedia katolicka, t. 15, red. E. Gigiliwicz, Lublin 2011, kol. 68.

${ }^{23}$ Zob. J. N. D. Kelly, Początki doktryny chrześcijańskiej, Warszawa 1988 (oryg. ang. 1977), s. 99. 
negowali istnienie trzech relacyjnych Osób w Trójcy. Według tej koncepcji Osoby boskie były wyłącznie sposobami (modus) samowyrażania się jednego i niepodzielnego Boga; różnice wewnątrztrynitarne nie istniały, a Ojciec i Syn zostali utożsamieni. Patrypasjoniści i sabelianiści głosili np. narodziny Ojca jako Syna i śmierć Ojca na krzyżu. Konsekwencją zniesienia różnic pomiędzy Osobami boskimi było zupełne utożsamienie przez patrypasjonistów natury boskiej i ludzkiej w Chrystusie. Chrystus posiadał de facto jedną naturę bosko-ludzką. W ciągu wieków teologia wypracowała ortodoksyjną wykładnię tego zagadnienia - Chrystus, jako jedna z trzech Osób boskich, był niecierpiętliwy w swojej boskiej naturze i doznawał cierpienia w swojej ludzkiej naturze ${ }^{24}$. Odpowiedź ta była powszechnie akceptowana i aż do końca XIII w. patrypasjonizm pozostawał wyłącznie wspomnieniem dawnych sporów i błędów. Przypomniano sobie o nim dopiero w pierwszej ćwierci XIV w., kiedy pojawiły się nowe, inspirowane mistycyzmem ruchy religijne ${ }^{25}$.

W kontekście naszego studium i poszukiwań genezy poglądów Mikołaja Duthorowa na szczególną uwagę zasługuje wczesny czternastowieczny mistycyzm dominikański. Wyrósł on - jak celnie zauważył Alois M. Haas „ze spotkania zmysłu intelektualno-spekulatywnego z potrzebami duszpasterskimi" ${ }^{26}$. Za głównego twórcę i przedstawiciela tego nurtu uważa się Eckharta z Hochheim (1260-1327/28), znanego powszechnie jako Mistrz Eckhart ${ }^{27}$. Należał on do niemieckiej prowincji dominikanów i w niej głównie podejmował działalność dydaktyczną (jako mistrz świętej teologii) i duszpasterską (jako kaznodzieja i kierownik duchowy). Głównym motywem jego twórczości jest jedność w Trójcy i zjednoczenie człowieka z Bogiem. Oryginalność myśli, a przede wszystkim jego ogromna popularność wśród wiernych, doprowadziła najpierw do nieporozumień, a w końcu do

${ }^{24}$ Zob. T.G. Weinandy, Czy Bóg cierpi?, Poznań 2003 (oryg. ang. 2000); M. Przanowski, Krytyka koncepcji cierpienia Boga z perspektywy współczesnej myśli tomistycznej, „Studia Bobolanum" 2012, 3, s. 43-59.

${ }^{25}$ Zob. liczne studia w ramach tomu pt. Duchowość chrześcijańska, t. 2: Późne średniowiecze i reformacja, red. J. Raitt, Kraków 2011 (oryg. ang. 1987), a szczególnie R. Kieckhefer, Główne nurty pobożności późnego średniowiecza (s. 75-110), A. M. Haas, Szkoły późnośredniowiecznego mistycyzmu (s. 143-180).

${ }^{26}$ Zob. A. M. Haas, op. cit., s. 147.

${ }^{27}$ Literatura na temat Mistrza Eckharta jest bardzo obszerna, zob. szczególnie: F.J. Schweitzer, Meister Eckhart und der Laie: ein antihierarchischer Dialog des 14. Jahrhunderts aus den Niederlanden, Berlin 1997; S. Jäger, Meister Eckhart - ein Wort im Wort: Versuch einer theologischen Deutung von vier deutschen Predigten, Berlin 2008; Z. Kaźmierczak, Paradoks i zbawienie. Antropologia Mistyczna Mistrza Eckharta i Jana od Krzyża, Białystok 2009; Encyclopédie des mystiques rhénans d'Eckhart à Nicolas De Cues et leur réception, red. M.-A. Vannier, Paris 2011. 
oskarżenia o głoszenie heretyckich poglądów ${ }^{28}$. Ostatnie lata swojego życia Mistrz Eckhart spędził na bronieniu swojej niewinności: najpierw w Kolonii przed dwoma dominikańskimi wizytatorami (1325) w trakcie kapituły prowincjalnej, następnie przed sądem biskupa kolońskiego (1325-1326), wreszcie na początku roku 1327 również przed sądem papieskim w Awinionie $^{29}$. Tam też lub w drodze powrotnej stamtąd zmarł pod koniec $1327 \mathrm{r}$. lub wiosną $1328 \mathrm{r}$. Sprawa niemieckiego dominikanina odbiła się głośnym echem w całym zakonie, czego ślady odnajdujemy w przytaczanych już wyżej zarządzeniach kapituły generalnej w Tuluzie, zakazujących braciom głoszenia kontrowersyjnych kazań ${ }^{30}$. W niecały rok po śmierci dominikańskiego teologa, 27 marca 1329 r. papież Jan XXII w bulli In agro dominico zakwestionował prawowierność 28 twierdzeń pochodzących z jego dzieł ${ }^{31}$. Papież jednak nie wszystkie przedstawione twierdzenia uznał za heretyckie, ale podzielił je na dwie grupy: 17 tez (art. 1-15, 27-28) zostało napiętnowanych jako heretyckie ${ }^{32}$, a 11 tez (16-26) zostało uznanych za błędne, źle brzmiące i lekkomyślne, które jednak po dodatkowych wyjaśnieniach i uzupełnieniach mogą być przyjęte przez Kościół ${ }^{33}$. Wśród tych 11 errores warto dokładniej przyjrzeć się dwu z nich - orzeczeniom 23 i 24:

$23^{\text {us }}$ articulus. Deus est unus omnibus modis et secundum omnem rationem, ita ut in ipso non sit invenire aliquam multitudinem in intellectu vel extra intellectum; qui enim duo videt vel distinctionem videt, Deum non videt. Deus enim unus est extra numerum et supra numerum, nec ponit in unum cum aliquo. Sequitur: Nulla igitur distinctio in ipso Deo esse potest aut intelligi.

$24^{\text {us }}$ articulus. Omnis distinctio est a Deo aliena, neque in natura neque in personis. Probatur: quia natura ipsa est una et hoc unum, et quelibet persona est una et id ipsum unum quod natura ${ }^{34}$.

${ }^{28}$ Warto przytoczyć tutaj niezwykle trafną uwage Simona Tugwella OP: „Eckhart zbyt wiele czasu spędził w otoczeniu słuchaczy darzących go podziwem, lecz niewykazujących należytego krytycyzmu i zrozumienia, przez co nigdy nie został zmuszony do klarownego wyłożenia swojej nauki", zob. S. Tugwell, Mendykanci. Duchowość dominikańska, w: Duchowość chrześcijańska, s. 27-28.

${ }^{29}$ Zob. B. McGinn, Eckhart's Condemnation Reconsidered, „The Thomist” 44, 1980, 390-414; J. Devriendt, Procès de maître Eckhart, w: Encyclopédie des mystiques rhénans, s. $983-1003$.

${ }^{30}$ Zob. przyp. 12.

${ }^{31}$ Zob.R. E. Lerner, New Evidence for the Condemnation of Meister Eckhart, ,Speculum” 72, 1997, 2, s. 345-366, edycja bulli In agro dominico s. 363-366; J. Devriendt, op. cit., s. 996-999.

32 Zob.: „Tam ex suorum sono verborum quam ex suarum connexione sententiarum errorem seu labem heresis continere”, R. E. Lerner, op. cit., s. 365.

${ }^{33}$ Zob.: ,Nimis male sonare et multum esse temerarios de heresique suspectos, licet cum multis expositionibus et suppletionibus sensum catholicum formare valeant vel habere", ibidem.

${ }^{34}$ Ibidem, s. 364-235. 
Artykuły 23 i 24 bulli In agro dominico kwestionowały Eckhartowską naukę o wewnętrznej niepodzielności Trójcy. Pozostawiając na boku kwestię zasadności ich zarzutów i w ogóle tego, czy trafnie ujmowały doktrynę i tezy tekstów Eckharta, warto zauważyć, że artykuł 23 zawierał pierwszy argument, jaki został wytoczony przeciw Eckhartowi jeszcze w trakcie procesu kolońskiego w $1325 \mathrm{r}^{35}$ Artykuł ten, wraz z następnym, był fundamentem wszystkich innych zarzutów formułowanych przeciwko niemu. Wyrażona przez Eckharta teza, że „nulla distinctio in ipso Deo”, rodziła podejrzenie o negację wzajemnych relacji Osób w Trójcy. Tak mocne podkreślenie jedności Osób Boskich mogło w konsekwencji prowadzić do podważenia ortodoksyjnej nauki o Bogu Trójjedynym. Z kolei w artykule 24 wprost stwierdzono, jakoby Eckhart głosił jedność Osób w Trójcy nie tylko na płaszczyźnie ich wspólnej natury (in natura) ale i wspólnej jednej Osoby (in personis). W domyśle: Osoby w Trójcy są tożsame ${ }^{36}$.W ten sposób argument 24 stał się głównym dowodem na występowanie elementów sabelianizmu w naukach Mistrza Eckharta ${ }^{37}$. Mimo że sam dominikanin odżegnywał się od wszelkich związków z tą herezją i wprost deklarował przywiązanie do ortodoksyjnej doktryny trynitarnej, to oskarżenia o modalizm na trwałe wpisały się w ocenę jego doktryny.

Powiązanie Eckharta z modalizmem miało swoje dalsze reperkusje. Wraz z pojawieniem się w 1329 r. papieskiej listy zarzutów zaczęto nieufnie przyglądać się całej jego twórczości i wysunięto inne oskarżenia pod adresem nieżyjącego już Eckharta. Zgłoszono m.in. szereg wątpliwości co do jego chrystologii ${ }^{38}$. Wśród najpoważniejszych zarzutów należy wymienić dwa. Pierwszym miało być błędne rozumienie doktryny o dwóch naturach Chrystusa. Eckhart, według jego przeciwników, miał twierdzić, że Osoba Syna była do tego stopnia jednością, iż różnice pomiędzy naturami ludzką i boską uległy jeżeli nawet nie zniesieniu, to „zatarciu”.Jak pokazały najnowsze badania Marie-Anne Vannier, oskarżenie to było całkowicie bezpodstawne ${ }^{39}$. Drugi błąd w chrystologii Eckharta miał być związany

${ }^{35}$ Zob. J. Devriendt, op. cit., s. 999.

${ }^{36}$ Zob. Mistrz Eckhart, Pouczenia duchowe. Wybór traktatów i kazań, Poznań 2001, s. 93-94, przyp. 7.

${ }^{37}$ Zob.: „They also felt that the second article, in its denial of distinction in God either in nature or in Persons (note that Eckhart did not say inter personas), was reducible to Sabellianism", B. McGinn, op. cit., s. 410.

${ }^{38}$ Zob. É.H. Wéber, Le Christ selon Maitre Eckhart, w: Christ among the Medieval Dominicans, red. K. Emery, J.P. Wawrykow, Notre Dame, Ind. 1998, s. 414-429; M.-A. Vannier, Christologie. Eckhart, w: Encyclopédie des mystiques rhénans, s. 240-243.

${ }^{39}$ Zob.: „Vivant au XIVe siècle, dans une civilisation chrétienne, et non à l'époque patristique, il ne revient pas à Eckhart de développer la christologie en réaction contre des hérésies diverses. Sur ce point, il bénéficie d'ailleurs de l'acquis de ses pré- 
z jego interpretacją tradycyjnego rozróżnienia Syna przez naturę i synów poprzez usynowienie ${ }^{40}$. Dominikanin nadał tej doktrynie własne, oryginalne zabarwienie. Ponieważ Słowo przyjęło naturę ludzką, wspólną wszystkim ludziom, to w Osobie Syna stajemy się synami w identyczny sposób, jak sam Chrystus. Oczywiście, doktryna ta u jednych wzbudziła podejrzenia ${ }^{41}$, a u innych położyła fundament pod twierdzenia teologicznie zbyt śmiałe i sprzeczne z myślą Eckharta. Skrajną nadinterpretacją tej doktryny było utożsamienie człowieka z Chrystusem - to człowiek jest Druga Osobą Boską ${ }^{42}$. Częściej natomiast sięgano do intuicji Eckharta, gdy chciano podkreślić tożsamość doświadczeń (doznań fizycznych) człowieka i Chrystusa - np. cierpienie człowieka jest zarazem cierpieniem Boga, a cierpienie Boga mogło być doznawane i naśladowane przez człowieka (imitatio passionis). Pomimo że Eckhart w niewielkim stopniu interesował się zewnętrznymi praktykami pasyjnymi, takimi jak medytacja nad skrwawionym Jezusem na krzyżu, nie mówiąc już o fizycznych próbach zadawania sobie takich cierpień, to jednak nie była mu obca teologiczna kwestia cierpienia, w tym cierpienia Boga i samego Chrystusa ${ }^{43}$. Rozróżniał zewnętrzne cierpienia Chrystusa i Jego wewnętrzną stałość w Bogu, przy czym nie odwoływał się bezpośrednio do klasycznej doktryny impassibilitas Dei ${ }^{44}$. Co więcej, niejednokrotnie odnajdujemy w jego dziełach fragmenty, które zdają się podważać tę ortodoksyjną doktrynę. W ramach przykładu można przywołać komentarz Eckharta umieszczony w Księdze boskich pocieszeń. Komentując biblijne słowa: „Błogosławieni, którzy cierpią prześladowanie” (Mt 5,3), odwołał się on do problemu tożsamości głębi duszy i głębi Boga, by stwierdzić, że gdy człowiek świadomie przyjmuje cierpienie, to wówczas cierpi

décesseurs, il distingue les deux natures dans l'unique personne du Christ", ibidem, s. 240. Zob. także É. H. Wéber, op. cit., s. 422.

${ }^{40}$ Zob. B. McGinn, Mistyczna myśl Mistrza Eckharta, Kraków 2009 (oryg. ang. 2001), s. 118-130, szczególnie s. 120-121.

${ }^{41}$ Warto zauważyć, że już w bulli In agro dominico napiętnowano takie rozumienie problemu synostwa, zob. art. 11: „Quicquid Deus pater dedit filio suo unigenito im humana natura, hoc totom dedit michi. Hic nichil excipio, nec unionem nec sanctitatem, sed totum dedit michi sicut sibi", R. E. Lerner, op. cit., s. 364.

${ }^{42}$ Według B. McGinna sam Eckhart nie sprzeciwiłby się od razu temu, wydawałoby się heretyckiemu twierdzeniu. „Czy oznacza to, że my sami stajemy się Drugą Osobą Trójcy? Zdaniem Eckharta, tak i nie. Tak, w tym sensie, że istnieje tylko jedno Synostwo, którym nie jest nikt inny jak Osoba Słowa; nie, w tym sensie, że rodzimy się synami Boga poprzez usynowienie”, zob. B. McGinn, Mistyczna myśl, s. 121.

${ }^{43}$ Zob. D.F. Duclow, „My Suffering is God”. Meister Eckhart's Book of „Divine Consolation”, „Theological Studies” 44, 1983, 4, s. 570-586; A. M. Haas, „Trage Leiden geduldiglich". Die Einstellung der deutschen Mystik zum Leiden, w: idem, Gott Leiden - Gott Lieben: Zur volkssprachlichen Mystik im Mittelalter, Frankfurt a.M. 1989, s. 127-152; É. Mangin, Souffrance, w: Encyclopédie des mystiques rhénans, s. 1087-1091.

${ }^{44}$ Zob.É. H. Wéber, op. cit., s. 422; M.-A. Vannier, op. cit., s. 242. 
także Bóg: „Moje cierpienie staje się cierpieniem Boga i samym Bogiem”45. Eckhart tak bardzo chciał przedstawić zagadnienie Boga z perspektywy jego jedności i zjednoczenia Boga z człowiekiem, że problem różnic i odmienności zszedł na odległy, wręcz niewidoczny plan. Celem bowiem, jaki obrał sobie dominikanin, było pokazanie ludziom ich niejako „istotowego" podobieństwa z Bogiem ${ }^{46}$.

Śmierć Eckharta i publikacja bulli In agro dominico nie zatrzymały procesu rozpowszechniania się jego doktryny. Roli głównego kontynuatora i zarazem obrońcy Eckharta podjął się inny dominikanin niemiecki bł. Henryk Suzo (1295-1366), znany również jako frater Amandus ${ }^{47}$. Był on uczniem Eckharta w dominikańskim studium w Kolonii, a później również przeorem i lektorem konwentualnym w Konstancji. Od 1335 r. aż do śmierci Henryk zajmował się wyłącznie pracą duszpasterską, głównie cura monialium, oraz przygotowaniem licznych traktatów, listów, kazań oraz autobiografii. W twórczości Henryka odnajdujemy szereg nawiązań do myśli Eckharta, aczkolwiek - trzeba to podkreślić - Suzo, jak zobaczymy dalej, koncentrował się na nieco innych zagadnieniach ${ }^{48}$. Dla nas najważniejsze jest jedno jego dzieło, powstałe w Konstancji w latach 1328-1329: Bücherlein der ewigen Weisheit, czyli Księga (lub Książeczka) Mądrości przedwiecznej ${ }^{49}$. Warto zasygnalizować, że kilkadziesiąt lat później (ok. 1362 r.) Suzo wydał to dzieło ponownie w nowej, wzbogaconej o wątki autobiograficzne, wersji łacińskiej jako Horologium Sapientioe ${ }^{50}$. Bücherlein der ewigen Weisheit było, według Bernarda McGinna, „najsłynniejszym dziełem dewocyjnym późnego średniowiecza" ${ }^{1}$. Dzieło składa się z trzech części. Pierwsza z nich, najobszerniejsza, zawiera 20 rozważań na temat cierpienia Chrystusa, przedstawionych w formie dialogu pomiędzy Sługą, którym jest sam Henryk, a Mądrością Przedwieczną, czyli Chrystusem. Suzo zainicjował tutaj swój ulubiony temat, który on sam nazywał „drogą królewską" (via regia), mianowicie konieczność przejścia przez cierpienie Chrystusa, by osiągnąć kontemplację i zjednoczenie z Bogiem ${ }^{52}$. Druga

${ }^{45}$ Mistrz Eckhart, Traktaty, Poznań 1987, s. 119.

${ }^{46}$ Zob. B. McGinn, Mistyczna myśl, s. 127.

47 Zob. S. B. Bancel, A. M. Haas, M. Enders, Henri Suso, w: Encyclopédie des mystiques rhénans, s. 1123-1134 (tam obszerna bibliografia). W 1831 r. papież Grzegorz XVI ogłosił Henryka Suzo błogosławionym.

${ }^{48}$ Zob. H. Piesch, Seuses „Büchlein der Wahrheit” und Meister Eckhart, w: Heinrich Seuse: Studien zum 600 Todestag 1366-1966, red. E. M. Filthaut, Köln 1966, s. 91-134.

${ }^{49}$ Zob. Henryk Suzo, Księga mądrości przedwiecznej, Poznań 1983.

${ }^{50}$ Zob. J. Ancelet-Hustache, Quelques indications sur les manuscrits de l'Horologe de Sapience, w: Heinrich Seuse: Studien, s. 161-170.

${ }^{51}$ Zob. B. McGinn, Mistyczna myśl, s. 158.

${ }^{52}$ Zob. J. Bühlmann, Christuslehre und Christusmystik des Heinrich Seuse, Lucerne 1942, s. 197-214. 
część dotyczy zagadnienia śmierci fizycznej i duchowej. W czterech rozdziałach dominikanin podjął medytację nad faktem śmierci Chrystusa i sytuacją człowieka w obliczu nieuchronności śmierci ${ }^{53}$. Trzecia część zbudowana jest wokół stu inwokacji skierowanych do cierpiącego Chrystusa i Maryi, które Henryk miał zwyczaj wypowiadać w trakcie codziennej modlitwy.

Najbardziej charakterystyczną cechą jego doktryny jest mistyka cierpienia i chrystocentryzm ${ }^{54}$. Suzo nie poprzestawał na „teoretycznej” chrystologii Eckharta, ale poszedł dalej i nadał jej wymiar konkretny i praktyczny. Dlatego też na pierwszy planie postawił mękę i krzyż Chrystusa, którego przedstawił jako Mądrość Przedwieczną. Człowiek miał upodobnić się do Chrystusa poprzez podjęcie drogi wyrzeczenia, cierpienia i śmierci. W rezultacie Henryk ukształtował nową „filozofię cierpiącego Chrystusa”, zwaną również mistycyzmem pasyjnym. Bücherlein nie było traktatem dogmatycznym, ale tekstem dewocyjnym, który miał przede wszystkim pomóc niemieckojęzycznemu czytelnikowi w rozwoju indywidualnej pobożności. Język Henryka jest prosty i emocjonalny, a zarazem mocno metaforyczny ${ }^{55}$. Z tych też powodów próżno szukać w dziele Henryka precyzyjnie wyłożonej doktryny cierpienia Chrystusa w kontekście natury unii hipostatycznej i koncepcji impassibilitas Dei. Pisząc o męce Chrystusa, dominikański autor nie rozgranicza cierpienia ludzkiej natury Osoby Syna i niepodlegania doznaniom przez jego naturę boską. Nie dziwi zatem obecność takich sformułowań: „Twoje Boskie uszy napełniły się szyderstwami i bluźnierstwami”, „Twoja natura grzęzła w bezdennym smutku, ale Twoje zgnębione serce od nikogo nie mogło otrzymać pociechy”, „Twoja Boska głowa skłoniła się od bólu i cierpienia" ${ }^{56}$. Oczywiście nie można się w nich doszukiwać ewidentnych dowodów na propagowanie przez Henryka patrypasjonizmu, niemniej jednak treści tego typu musiały wzbudzać nieufność teologów i podejrzenia o heterodoksyjność. I rzeczywiście, niedługo po publikacji Bücherlein wywołała kontrowersje wśród samych dominikanów. W 1332 r., podczas kapituły prowincjalnej w Trewirze, Henrykowi postawiono zarzut głoszenia poglądów błędnych i heretyckich. Nie znamy niestety ani szczegółów tego procesu, ani listy zarzutów. Najprawdopodobniej, jak przypuszcza Loris Sturlese, chodziło z jednej strony o propagowanie nauk Eckharta, a z drugiej wątpliwości co do prawowierności

${ }^{53}$ Rodział 21 był często kopiowany i rozpowszechniany w formie osobnej publikacji pod tytułem Ars moriendi.

${ }^{54}$ Zob. J. Misiurek, „Złoty okres” niemieckiej mistyki, Lublin 1992, s. 89.

${ }^{55}$ Zob. S. B. Bancel, A. M. Haas, M. Enders, op. cit., s. 1130.

${ }^{56}$ Henryk Suzo, op. cit., s. 185, 191. 
nauk zawartych w Bücherlein ${ }^{57}$. Proces Henryka zakończył się dla niego szczęśliwie i już w 1334 r. generał zakonu Hugo de Vaucemain oczyścił niemieckiego dominikanina z wszystkich zarzutów ${ }^{58}$.

Na zakończenie prezentacji sylwetek i doktryny dominikańskich mistyków warto zatrzymać się jeszcze przy jednym interesującym fakcie: zarówno w wypadku Mistrza Eckharta, jak i Henryka Suzo tymi, którzy jako pierwsi wnieśli przeciw nim oskarżenia, nie byli ludzie spoza zakonu, np. lokalny biskup, ale sami dominikanie. Sytuacje te można próbować wytłumaczyć na kilka sposobów. Po pierwsze, nie można wykluczyć zwykłej niechęci ze strony współbraci, co rzeczywiście miało miejsce w przypadku Eckharta ${ }^{59}$. Nie bez znaczenia była również skomplikowana sytuacja Kościoła w latach dwudziestych i trzydziestych XIV w. Toczył się wówczas sławny spór o rozumienie ubóstwa pomiędzy papieżem Janem XXII a grupa franciszkańskich spirytuałów ${ }^{60}$. Dominikanie w sporze tym - o czym powiem nieco dalej - stanęli zdecydowanie po stronie papieża, jako oddani i prawowierni jego współpracownicy. W takim kontekście procesy Eckharta i Henryka, oskarżanych o podważanie nauki Kościoła, byłyby dowodem bezkompromisowej walki zakonu o czystość wiary. Można by też sformułować jeszcze jedno możliwe wyjaśnienie: być może nie tyle animozje wśród zakonników czy sytuacja zewnętrzna Kościoła wywołały procesy przeciwko Eckhartowi i Henrykowi, ile były one konsekwencją wewnętrznej polityki zakonu wobec pojawiających się wówczas nurtów religijnych i intelektualnych. Kiedy obserwujemy dominikanów pierwszej połowy XIV w. z perspektywy ich podejścia do problemu dyscypliny umysłowej, zauważamy pewien ściśle określony „program”. Możemy go streścić w dwóch terminach, zaczerpniętych z prologu trzynastowiecznych zakonnych konstytucji: uniformitas i unitas ${ }^{61}$. W 1305 r. na kapitule generalnej w Genewie został ustalony jeden, obowiązujący w całym zakonie, system szkolnictwa dominikańskiego ${ }^{62}$. Cztery lata później, w 1309 r., kapituła generalna w Za-

${ }^{57}$ Zob. L. Sturlese, Einleintung, w: Heinrich Seuse, Das Buch der Wahrheit, wyd. L. Sturlese, R. Blumrich, Hamburg 1993, s. XVII-XVIII, przyp. 24.

${ }^{58}$ Zob. S. B. Bancel, A. M. Haas, M. Enders, op. cit., s. 1124.

${ }^{59}$ Zob. J. Devriendt, op. cit., s. 984-985.

${ }^{60}$ Zob. przyp. 123-124 niniejszego artykułu.

${ }^{61}$ Zob.: „Quoniam ex precepto regule iubemur habere cor unum. et animam unam in Domino, iustum est ut qui sub una regula et unius professionis uoto uiuimus. uniformes in obseruantiis canonice religionis inueniamur: quatinus unitatem que interius seruanda est in cordibus, foueat et representet uniformitas exterius seruata in moribus", Constitutiones antique Ordinis Fratrum Prcedicatorum, prol. s. 311.

${ }^{62}$ Zob. MOPH, t. 4, s. 12; na temat szkolnictwa dominikańskiego w średniowieczu zob. K. Kaczmarek, op. cit.; M. Zdanek, Szkoły i studia krakowskich dominikanów, Kraków 2005; T. Gałuszka, Szkolnictwo, s. 191-212. 
grzebiu przyjęła jeden program nauczania oparty na twórczości jednego autora - św. Tomasza z Akwinu ${ }^{63}$. Ważnym wydarzeniem w realizacji tego postanowienia była kanonizacja Akwinaty w 1323 r., która definitywnie potwierdziła jego czołową pozycję w zakonie dominikańskim ${ }^{64}$. Jednak o ile w wypadku uniformizacji struktur szkolnictwa nie obserwujemy sprzeciwu ze strony braci, o tyle polityka ,,jednej doktryny" nie spotkała się z natychmiastową akceptacją. Jeszcze w 1355 r. dominikanie zebrani na kapitule generalnej w Pampelunie musieli przypomnieć wszystkim współbraciom, że jedyną zdrową nauką jest myśl Tomasza z Akwinu ${ }^{65}$. Ponadto kapituła owa surowo skrytykowała tych, którzy poszukiwali próżnej wiedzy i ciekawostek teologicznych (in scienciis vanis et curiosis conclusionibus). Skarcono wówczas braci, którzy dawali się ponieść „,czczej gadaninie, próżnym doktrynom oraz ciekawości" ${ }^{66}$. W określeniach vaniloquim, vana doctrina, vana scientia - jak zauważył William J. Courtenay - należy widzieć nie tylko krytykę innych niż tomizm nurtów filozoficzno-teologicznych, ale przede wszystkim ostrzeżenie przed naukami, które lekceważyły ortodoksyjną doktrynę i zwyczaje Kościoła ${ }^{67}$. Wśród głównych podejrzanych byli propagatorzy nowych form pobożności - również mistycy ${ }^{68}$. W tym kontekście w pełni zrozumiałe stają się powody nieufności i podejrzenia ze strony braci w stosunku do nauk głoszonych przez Eckharta i Henryka. Nawet jeśli ich dzieła nie były ewidentnie heretyckie i nie uderzały bezpośrednio w naukę Kościoła, to jednak wyraźnie osłabiały zakonną uniformitas. Bezpośrednią

${ }^{63}$ Zob.: „Volumus et districte iniungimus lectoribus et sublectoribus universis, quod legant et determinent secundum doctrinam et opera venerabilis doctoris fratris Thome de Aquino, et in eadem scolares suos informent, et studentes in ea cum diligencia studere teneantur. Qui autem contrarium fecisse notabiliter inventi fuerint nec admoniti voluerint revocare, per priores provinciales vel magistrum ordinis sic graviter et celeriter puniantur, quod sint ceteris in exemplum", MOPH, t. 4, s. 39. Postanowienie to było wielokrotnie przypominane na kolejnych kapitułach generalnych w latach: 1313, 1314, 1315, 1329, 1340, 1342, 1343, 1346, 1352, 1353, 1357, 1361.

${ }^{64}$ Zob. J.-P. Torrell, Tomasz z Akwinu - człowiek i dzieło, Warszawa 2008, s. 374-378; F. Amerini, The Reception of Thomas Aquinas' Philosophy in the Dominican studia of the Roman Province in the Fourteenth Century, w: Philosophy and Theology in the Studia of the Religious Orders and at the Papal Court, red. W.J. Courtenay, K. Emery, Turnhout 2012, s. 139-164.

65 „Inhibemus autem fratribus universis, ne in scienciis vanis et curiosis conclusionibus et peregrinis studeant vel insistant nec conversentur cum fratribus quibuscumque, qui docent seu predicant conclusiones temerarias, falsas, periculosas aut su spectas, maxime contrarias determinacioni sancte matris ecclesie et doctrine communi, et precipue doctrine sancti Thome diligencius insistendo. Quod si aliquis admonitus se non correxerit, ipso facto penam gravioris culpe se noverit incurrisse", MOPH, t. 4, s. 367.

${ }^{66}$ Ibidem, s. 280, 297, 313. Oskarżenie to było fere ad verbum powtórzeniem zarządzeń trzech wcześniejszych kapituł z lat 1342, 1344 i 1346.

${ }^{67}$ Zob. W. J. Courtenay, Duchowość a późny scholastycyzm, w: Duchowość chrześcijańska, s. 117-118.

${ }^{68}$ Zob. S. Tugwell, op. cit., s. 27. 
konsekwencją tej polityki była również ostra reakcja najwyższych władz zakonu na pojawiające się w dwudziestych i trzydziestych latach XIV w. wśród braci kaznodziejów tendencje spirytualistyczne. Temat ten przedstawię szerzej w trzeciej części niniejszego studium.

Podsumowując dotychczasowe analizy, widzimy wyraźnie, że pierwsza połowa XIV w. była czasem formowania się nowej pobożności chrześcijańskiej, której wyróżnik stanowiło podkreślenie mistycznej relacji z Bogiem. Pragnienie indywidualnego doświadczenia i zjednoczenia z Bogiem wyrażało się w podkreślaniu fizycznej z Nim bliskości i współodczuwania. Stąd jednym z charakterystycznych elementów tej duchowości była naturalistyczna, obrazowa i emocjonalna interpretacja cierpień Chrystusa ${ }^{69}$.Pobożność ta - co doskonale pokazują teksty Henryka Suzo - wytworzyła własną „mistyczną narracje”, która w miejsce technicznego i klarownego języka filozofii i teologii wprowadziła styl bezpośredni, potoczny i częstokroć niejasny ${ }^{70}$. Ważnym acz nie jednym medium rozpowszechnienia tych idei były różne teksty dewocyjne, wśród których wybija się twórczość wspomnianych już dominikańskich mistyków nadreńskich - Mistrza Eckharta i Henryka Suzo. Warto podkreślić, że oni też jako pionierzy czternastowiecznej mistyki dominikańskiej musieli jako pierwsi zmierzyć się z nieufnością i oskarżeniami ze strony swojego środowiska.

W świetle tych kilku uwag możemy powrócić do interesującej nas sprawy Mikołaja Duthorowa. Polscy dominikanie zabrani na kapitule prowincjalnej w $1338 \mathrm{r}$. musieli być poruszeni tym, co usłyszeli od (lub na temat) gryfijskiego współbrata. Miał on bowiem stwierdzić, że: „,[Chrystus] cierpiał nie tylko w ludzkiej naturze, ale również w boskiej”. Nie ulega zatem wątpliwości, że głównym tematem nauczania Mikołaja była kwestia męki Chrystusa. Można domniemywać, że jego dewocyjna i kaznodziejska żarliwość wykraczała daleko poza znane i akceptowane wówczas u dominikanów ramy dyskursu teologicznego. Oczywiście, bracia w żaden sposób nie byli przeciwnikami pobożności pasyjnej, czego najlepszym dowodem są choćby wezwania ich kościołów, które najczęściej, tj. w ośmiu przypadkach, były poświęcone św. Krzyżowi ${ }^{71}$. Co więcej, Męka Pańska i związana $\mathrm{z}$ nią pokuta stanowiły najważniejszy temat ich kazań. Ewidentnie zatem Mikołaj musiał rozpowszechniać pobożność pasyjną w formie dotąd nie-

${ }^{69}$ Zob. F. di Bernardo, Passion, w: Dictionnaire de spiritualité, t. 12, cz. 1, red. A. Rayez, A. Derville, A. Solignac, Paris 1984, kol. 328-331; R. Kieckhefer, op. cit., s. 84-90.

${ }^{70}$ Zob.É.H. Wéber, op. cit., s. 422.

${ }^{71}$ Zob. J. Kłoczowski, Dominikanie polscy na Śląsku w XIII-XIV wieku, Lublin 1956, s. 268-269; W. Rozynkowski, Święci patronowie kościoła dominikanów w Gdańsku - wokół średniowiecznych wezwań dominikańskich w Polsce, w: Dominikanie. Gdańsk - Polska - Europa, red. D. A. Dekański, A. Gołembnik, M. Grubka, Gdańsk-Pelplin 2003, s. 231-241. 
znanej polskim braciom, z nowym językiem i zapewne nowymi praktykami dewocyjnymi.

Nie wiemy jednak, czy przytoczona w aktach prowincjalnych błędna teza była dosłowną wypowiedzią Mikołaja, czy też sporządzoną przez kapitułę teologiczno-prawną parafrazą jego błędnych poglądów. Jeżeli przyjmiemy, że twierdzenie to rzeczywiście padło z ust Mikołaja, należałoby w nim widzieć wyznawcę jakiejś formy herezji trynitarnej (modalizm) i przeciwnika ortodoksyjnej nauki na temat impassibilitas Dei. W tej sytuacji oskarżenia wobec Mikołaja można by połączyć z zarzutami stawianymi w latach 1325-1329 Mistrzowi Eckhartowi i w 1332 r. Henrykowi Suzo. Zauważmy, że hipoteza ta znajduje swoje dodatkowe umocnienie w pewnej obserwacji źródłowej - bracia, badając sprawę Mikołaja, sięgnęli do konstytucji soborowej Damnamus, traktującej na temat principiów ortodoksyjnej trynitologii. Wiedzieli bowiem, że błędne rozumienie cierpienia Chrystusa w kontekście natury unii hipostatycznej ma swoje dalsze konsekwencje w postaci podważenia prawowiernej nauki o Trójcy, czego doskonałym przykładem były błędy starożytnych patrypasjonistów.

Jeżeli natomiast uznamy, że przytoczona w aktach teza Mikołaja jest wyłącznie sporządzonym przez kapitułę prowincjalną teologicznym streszczeniem sprawy gryfijskiego dominikanina, wówczas możliwe staje się także nieco inne wyjaśnienie - bracia błędnie zinterpretowali nauki Mikołaja i przypisali mu twierdzenia, których oskarżony ani nie głosił, ani też nie podzielał. W świetle tej drugiej hipotezy sprawę Mikołaja Duthorowa z 1338 r. należałoby rozpatrywać i oceniać z tej samej perspektywy co wcześniejsze procesy zakonne Mistrza Eckharta i Henryka Suzo. Bez względu jednak na to, które z dwóch zaproponowanych rozwiązań przyjmiemy, jest rzeczą pewną, że źródeł poglądów Mikołaja trzeba poszukiwać w rozwijającej się na początku XIV w. nowej pobożności pasyjnej i, najprawdopodobniej, w doktrynach mistyków dominikańskich - Eckharta i Henryka Suzo.

Czy jednak rzeczywiście Mikołaj miał dostęp do tekstów Eckharta i Henryka? W pierwszej połowie XIV w. dzieła obu mistyków znane były przede wszystkim w wersji średnio-wysoko-niemieckiej (Mittelhochdeutsch). Fakt, że zostały napisane w języku rodzimym, nie pozostał bez wpływu na ich szybką recepcję. Należy jednak pamiętać, że inaczej wyglądało rozprzestrzeniania się tekstów Mistrza Eckharta, a inaczej jego ucznia - Henryka Suzo ${ }^{72}$. Dostęp do dzieł pierwszego z mistyków został

${ }^{72}$ Zob. G. Steer, Édition des œuvres d'Eckhart, w: Encyclopédie des mystiques rhénans, s. 430-432; S. B. Bancel, A. M. Haas, M. Enders, op. cit., s. 1130. 
wyraźnie ograniczony potępieniem papieskim w 1329 r. Natomiast dzieła drugiego z dominikanów, po wspomnianych trudnościach w latach trzydziestych, zyskały aprobatę Kościoła i od drugiej połowy XIV w. weszły w skład podstawowej literatury dewocyjnej. Szczególnie jedno z jego dzieł, wspominane Bücherlein der ewigen Weisheit, wywarło ogromny wpływ na kształtowanie pobożności pasyjnej w XIV i XV w. Twórczość Henryka Suzo cieszyła się również dużą popularnością w Polsce średniowiecznej. W polskich zbiorach - jak pokazały badania Roberta Świętochowskiego OP zachowało się kilkanaście rękopisów z dziełami Suza, z których najstarszy pochodzi z końca XIV w. i przechowywany jest w Krakowie ${ }^{73}$. Niestety nie posiadamy analogicznych opracowań jeśli chodzi o rękopisy z tekstami Eckharta. Uwagi na temat wersji językowej i wczesnej recepcji Eckharta i Suza są dla nas o tyle istotne, że pozwalają już na wstępie zweryfikować zasadność postawionego wyżej pytania. Akta polskiej kapituły prowincjalnej z 1338 r. wprost informują, że Mikołaj wygłosił swoje poglądy w leżącym na Pomorzu Zachodnim klasztorze w Gryfii, które to miasto, jak wiadomo, przynależało do kręgu kultury języka niemieckiego. Uzasadnione jest więc przypuszczenie, że Mikołaj w trakcie głoszenia swoich errores condemnati posługiwał się językiem zrozumiałym dla swoich słuchaczy, tj.językiem niemieckim. A zatem nic nie stało na przeszkodzie, by Mikołaj bezpośrednio zapoznał się z twórczością mistyków nadreńskich. Dostęp do ich dzieł, a przede wszystkim czołowego eckhartysty - Henryka Suzo, mógł być o tyle łatwiejszy, że klasztor w Gryfii nie tylko sąsiadował z prowincją niemiecką, ale był z nią nolens volens w ścisłych relacjach ${ }^{74}$.

$\mathrm{Na}$ koniec tej sekcji warto zwrócić uwagę na jeszcze jeden interesujący fakt, który pozwala lepiej zrozumieć reakcję polskiej kapituły na nauki Mikołaja Duthorowa. Niewątpliwe, miejscowi dominikanie mieli liczne okazje, by zapoznać się z kontrowersjami wokół doktryny Eckharta i Suza choćby za sprawą kapituł generalnych, w których regularnie brali udział, czy też bezpośrednich kontaktów z prowincją niemiecką. Jednak - co warto podkreślić - wiarygodne informację na ten temat mogli uzyskać od jednego z najważniejszych uczestników polskiej kapituły z 1338 r. - niemieckiego dominikanina Jana de Tweebergen („,de Duobus Montibus") z Maastricht ${ }^{75}$. W 1337 r. kapituła generalna w Wa-

${ }^{73}$ Zob. R. Świętochowski, Der Einfluss und die Bedeutung des Seligen Heinrich Seuse in Polen, w: Heinrich Seuse: Studien, s. 409-436.

${ }^{74}$ Warto pamiętać o podejmowanych w latach 1279-1281 przez dominikanów niemieckich próbach oderwania klasztoru gryfijskiego od prowincji polskiej i włączenia go w struktury prowincji niemieckiej, zob. J. Kłoczowski, Dominikanie polscy nad Bałtykiem, s. 123-125.

${ }^{75}$ Zob. R.J. Loenertz, Un ancienne chronique des provinciaux dominicains de Pologne, 
lencji ustanowiła go wikariuszem prowincji polskiej i zobowiązała do zwołania kapituły prowincjalnej w $1338 \mathrm{r}^{76}$ Po wypełnieniu tego zadania Jan de Tweebergen powrócił do macierzystej prowincji i już w 1340 r. rozpoczął długi prowincjalat (1340-1354) ${ }^{77}$. Z pewnością polscy bracia w 1338 r., rozstrzygając sprawę Mikołaja Duthorowa, skorzystali z rady i doświadczenia niemieckiego dominikanina. Nie można wykluczyć, że Jan nie tylko posiadał wystarczającą wiedzę na temat poglądów Eckharta i Suza, ale również brał czynny udział w kapitułach prowincjalnych w Kolonii (1325) i Trewirze (1332), w trakcie których - jak wspominałem - zajmowano się oskarżeniami przeciwko jego dwóm współbraciom ${ }^{78}$.

\section{III}

Druga część interesującego nas fragmentu akt prowincjalnych z $1338 \mathrm{r}$. zawiera zarządzenie (ordinatio), rozpoczynające się od uroczystej promulgacji „Volumus, notificamus et imponimus”. Jego adresatami byli miejscowi inkwizytorzy papiescy, wywodzący się z zakonu kaznodziejskiego. Przypomnijmy krótko, że w 1338 r. inkwizycja papieska w Polsce była we wstępnej fazie organizacji. Zaledwie 11 lat wcześniej papież Jan XXII zezwolił polskiemu prowincjałowi dominikanów na wyznaczanie inkwizytorów papieskich dla obszaru Królestwa Polskiego ${ }^{79}$. W trzydziestych latach XIV w. funkcję inkwizytorów pełniło trzech dominikanów: Mikołaj ${ }^{80}$ na terenie Wielkopolski, Jan Schwenkenfeld ${ }^{81}$ na Śląsku i prawdopodobnie Stanisław z Krakowa ${ }^{82}$ w Małopolsce.

„Archivum Fratrum Prædicatorum” 21, 1951, s. 30, 49; T. Kaeppeli, Kapitelsakten der Dominikanerprovinz Teutonia $(1349,1407)$, „Archivum Fratrum Prædicatorum” 22, 1952, s. 187; M. Zdanek, Fragment, s. 266-267.

${ }^{76}$ Zob. MOPH, t. 4, 250-251.

77 Zob. A. Jundt, Histoire du Panthéisme populaire au Moyen Âge et au seizième siècle, Paris 1875, s. 289.

${ }^{78}$ Interesujące nas akta niemieckich kapituł prowincjalnych z lat 1325 i 1332 nie zawierają listy uczestników.

${ }^{79}$ Literatura na temat początków inkwizycji w Polsce jest bardzo obszerna, zob. szczególnie P. Kras, Działalność inkwizycyjna dominikanów krakowskich w średniowieczu, w: Mendykanci w średniowiecznym Krakowie, red. K. Ożóg, T. Gałuszka, A. Zajchowska, Kraków 2008, s. 390-391; W. Świeboda, Działalność inkwizytora Piotra OP w diecezji krakowskiej w latach 1403-1414, w: Kultura religijna i społeczna Małopolski od XIII do XVI wieku, red. W. Szymborski, J. Kozioł, Tarnów 2011, s. 111-113; T. Gałuszka, Kryzys w diecezji krakowskiej w 1. połowie XIV wieku? Z badań nad „Tractatus contra beghardos” Henryka Harrera, w: Ecclesia semper reformanda. Kryzysy i reformy średniowiecznego Kościoła, red. T. Gałuszka, T. Graff, G. Ryś, Kraków 2013.

${ }^{80}$ Zob. K. Kaczmarek, op. cit., s. 415, nr 54.

${ }^{81}$ Ibidem, s. 412, nr 39.

${ }^{82}$ Zob. M. Zdanek, Stanisław z Krakowa, PSB, t. 42, Kraków 2003-2004, s. 42-44; idem, 
Kapituła prowincjalna nakazała dominikańskim inkwizytorom ścigać i osadzać więzieniu osoby, które prowadziły singularem vitam i działały contra bonos mores. Wyjaśnijmy od razu, że wyrażenie vita singularis należy tłumaczyć jako życie prowadzone poza powszechnie przyjętymi strukturami i zwyczajami Kościoła (vita communis). Można je interpretować na dwa sposoby. Po pierwsze, w sensie szerszym vita singularis oznaczała każdą aktywność wiernych, która nie posiadała prawnej legitymizacji (zatwierdzenie, reguła, konstytucje zakonne itp.) wspólnoty Kościoła, w domyśle odpowiednich władz kościelnych. Vita singularis była zatem główną i wspólną cechą wszystkich średniowiecznych herezji ${ }^{83}$.W drugim, węższym rozumieniu vita singularis odnosiła się nie tyle do jakieś grupy osób, ile do pojedynczego chrześcijanina (duchownego lub świeckiego), który przekraczał ustalone przez Kościół normy i formy praktyk religijnych. W XIV w. tego typu zarzut stawiany był zazwyczaj zwolennikom radykalnego ubóstwa lub ruchów ascetyczno-mistycznych. Jeżeli chodzi o drugie oskarżenie, czyli o działanie contra bonos mores, kapituła mogła mieć na myśli osoby prowadzące życie niezgodne z obyczajnością publiczną (rozwiązłość, przestępstwa itp.) lub z powszechnie przyjętymi obyczajami Kościoła.Jednak brak precyzji i wielość możliwych interpretacji odnośnie do obu zarzutów nie musi automatycznie prowadzić do wniosku, że polska kapituła z 1338 r. nie wskazała konkretnej grupy podejrzanych, którymi mieli zająć się miejscowi inkwizytorzy. Zanim jednak przedstawię propozycję ich identyfikacji, należy najpierw wyjaśnić sam fakt wystosowania przez kapitułę zarządzenia do inkwizytorów.

Zarządzenie z 1338 r. możemy potraktować jako dobrą ilustrację związków, jakie występowały w XIV w. pomiędzy dominikańskimi inkwizytorami papieskimi a ich zakonnymi przełożonymi, tj. prowincjałem i generałem zakonu. Od drugiej połowy XIII w. obserwujemy systematyczne ograniczanie niezależności inkwizytorów papieskich i większą kontrolę nad ich dzia-

Inkwizytorzy dominikańscy $w$ diecezji krakowskiej w średniowieczu, w: Inkwizycja papieska w Europie Środkowo-Wschodniej, red. P. Kras, Kraków 2009, s. 234, nr 10. Z podanej przez M.Zdanka listy krakowskich inkwizytorów wykluczyłem postać dominikanina Henryka Harrera, który miałby pełnić officium inquisitionis w latach 1337-1343/1344. W wyniku nowych prac nad jego biografią i dziełem Contra beghardos okazało się, że należał on nie do polskiej, ale do czeskiej prowincji dominikanów, zob. T. Gałuszka, Harrer (Havrer) Henryk, w: Encyklopedia filozofii polskiej, red. A. Maryniarczyk i in., t. 1, Lublin 2011, s. 475-476 (tam pełna bibliografia).

${ }^{83}$ Zob. J.-C. Schmitt, Mort d'une hérésie. L'Église et les clercs face aux béguines et aux béghards du Rhin supérieur du XIVe au XVe siècle, Paris-La Haye-New-York 1978, s. 111-113; T. Gałuszka, Krakowscy pobożni laicy czy begardzi heretycy? Z badań nad czternastowiecznym „Tractatus contra begharodos” Henryka Harrera, „Folia Historica Cracoviensia" 18, 2012, s. 47-73. 
łalnością ${ }^{84}$. Zgodnie z postanowieniami kapituły generalnej w Bolonii z 1275 r. dominikańscy inkwizytorzy papiescy mieli obowiązek uczestniczenia w zakonnych kapitułach prowincjalnych ${ }^{85}$. W $1291 \mathrm{r}$. prowincjałowie dominikańscy otrzymali prawo napominania braci pełniących urząd inkwizytora ${ }^{86}$, a od 1294 r. mogli również kontrolować ich finanse ${ }^{87}$. Wreszcie, sobór w Vienne (1311-1312), w dekrecie XXVI (Multorum querela), w sposób definitywny potwierdził bezpośredni nadzór przełożonych zakonnych nad inkwizytorami, dając im prawo do usuwania ich z urzędu i nakładania na nich kar kanonicznych, w przypadku jakichkolwiek nieprawidłowości lub też nadużyć. Zrezygnowano również z zasady bezpośredniego podporządkowania inkwizytorów papieżowi ${ }^{88}$. Postanowienie soborowe zostało również powtórzone na kapitule generalnej w 1324 r., kiedy to nakazano inkwizytorom, by pod karą usunięcia z urzędu składali swoim przełożonym coroczne sprawozdanie finansowe ${ }^{89}$. W tym kontekście obecność zarządzenia w aktach polskiej kapituły z 1338 r. jest w pełni zgodna z ówczesną polityką zakonną. Warto jednak zauważyć, że kapituła wyraźnie poszerzyła swoje kompetencje i poza kontrolowaniem zakonnych inkwizytorów wyznaczyła im również nowe obowiązki. Ponadto, polscy dominikanie obdarzyli ich konkretną władzą - potestas libera incarcerandi. Inkwizytorzy mogli swobodnie wyszukiwać podejrzanych i osadzać ich w więzieniu. To ostatnie postanowienie jest o tyle zastanawiające, że każdy inkwizytor papieski w procesach dotyczących herezji posiadał taką władzę na mocy sprawowanego urzędu i nie potrzebował dodatkowych pozwoleń ze strony władz zakonnych ${ }^{90}$. Obecność zatem tej specjalnej

${ }^{84}$ Zob. P. Kras, Ad abolendam, s. 175-184.

${ }^{85}$ Zob. MOPH, t. 3, s. 181. Przepis ten został również powtórzony w 1285 r. przez kapitułę generalną (ibidem, s. 228).

${ }^{86}$ Zob.: „Inquisitores heretice pravitatis officium suum solito diligencius exequantur. alioquin per priores provinciales corrigantur", ibidem, s. 262 .

87 Zob. ibidem, s. 272-273.

${ }^{88}$ Zob. DSP, t.2, s. 586-591.

${ }^{89}$ Zob.: „Cum ad exaltacionem catholice fidei inquisitores heretice pravitatis omni nota cupiditatis aut nimie sumptuositatis mundos esse deceat et immunes, districtione, qua possumus, imponimus inquisitoribus universis, quod singulis annis, semel de receptis et expensis pro inquisicionis officio suis provincialibus racionem reddant claram et integram et perfectam. Et volumus, quod provinciales eorum racionem ab eis exigant, eciam per preceptum. Quicumque autem in venti fuerint in pecuniarum recepcionibus vel in immoderatis expensis notabiliter excessisse, a suis officiis absolvantur", MOPH, t. 4, s. 163.

${ }^{90}$ Zob.: „Decernimus exerceri sic quod quilibet de prædictis sine alio citare possit et arrestare sive capere ac tutæ custodiæ mancipare ponendo etiam in compedibus vel manicis ferreis si ei visum fuerit faciendum super quo ipsius conscientiam oneramus nec non inquirere contra illos de quibus pro huiusmodi negotio secundum deum et iustitiam viderit expedire", DSP, t. 2, s. 586. Zob. także P. Kras, Ad abolendam, s. 343-345. 
licencji w treści zarządzenia wskazuje, że zadanie, którego mieli się podjąć inkwizytorzy, wykraczało poza zwyczajne officium inquisitionis i generalnie nie dotyczyło ścigania „oficjalnych” heretyków, którymi inkwizytorzy i tak zajmowali się ex officio. Kogo zatem mieli na myśli polscy dominikanie?

W rozwiązaniu tej trudności nie możemy pominąć prostego faktu, mianowicie zarządzenie zostało umieszczone w aktach prowincjalnych, które zgodnie ze specyfiką zakonnych tekstów prawnych dotyczyły wyłącznie dominikanów i wewnętrznych spraw prowincji. Brak w nich tematów ogólnokościelnych i społeczno-politycznych. Już choćby z tego względu głównych podejrzanych powinniśmy poszukać przede wszystkim wśród samych dominikanów. Przypuszczenie to - jak zobaczymy dalej - znajduje potwierdzenie w trakcie analizy źródłowej.

W pierwszej kolejności przyglądnijmy się treści promulgacji. Została ona skonstruowana z trzech czasowników: „Volumus, notificamus et imponimus". Zauważmy, że tego typu trójelementowego zwrotu nie spotykamy ani w średniowiecznych aktach kapituł generalnych zakonu, ani znanych aktach kapituł innych prowincji. Z kolei sformułowanie volumus et imponimus występuje zaledwie czterokrotnie w średniowiecznych aktach kapituł generalnych. Interesujące, że ten podwójny zwrot pojawia się wyłącznie w XIV w. w tekstach postanowień kapituł z lata 1310-1336. We wszystkich tych przypadkach zestawienie tych czasowników miało na celu wzmocnienie i podkreślenie wagi jakiegoś zarządzenia władz zakonu dotyczącego życia wewnątrz prowincji oraz kwestii ogólnozakonnych ${ }^{91}$. Jednak na szczególną uwagę zasługuje obecność czasownika notificamus, który inaczej niż to było w przypadku zwrotu volumus i imponimus - pojawia się niezwykle rzadko w średniowiecznych tekstach prawnych zakonu. W trzynasto- i czternastowiecznych aktach kapituł generalnych mamy zaledwie 3 promulgacje rozpoczynające się od tego słowa ${ }^{92}$. We wszystkich tych przypadkach mamy do czynienia ze sprawami, które osobiście rozstrzygał lub dodatkowo potwierdzał generał zakonu. Dodajmy jeszcze, że w XV w. odnajdujemy kolejne dwa przykłady użycia zwrotu notificamus - pierwszy raz przy ogłoszeniu decyzji papieskiej i drugi w zarządzeniu potwierdzonym pieczęcią generała zakonu ${ }^{93}$. W świetle tej ostatniej obserwacji zarządzenie z 1338 r. możemy potraktować nie tyle jako niezależną inicjatywę polskiej kapituły prowincjalnej, ile odpowiedź na postulaty wysuwane wówczas przez najwyższe władze zakonu. Były one bardzo konkretne. Polityka zakonu dominikańskiego w pierwszej połowie XIV w. - o czym pisa-

\footnotetext{
${ }^{91}$ Zob. MOPH, t. 4, s. 54, 92, 93, 237.

${ }^{92}$ Zob. ibidem, t. 3, s. 282; t. 4, s. 208

${ }_{93}$ Zob. ibidem, t. 8, s. 80, 109.
} 
łem już wyżej - koncentrowała się wokół idei uniformitas. Z dużą więc nieufnością patrzono na wszelką aktywność duszpasterską i dewocyjną braci, która odbiegała od powszechnie przyjętych zwyczajów zakonu. Przyglądając się ustawodawstwu dominikańskiemu z dwudziestych i trzydziestych lat tegoż wieku, łatwo zauważyć, że kapituły generalne skoncentrowały się na walce z ruchami i tendencjami spirytualistycznymi wewnątrz zakonu. Wszystkimi możliwymi środkami chciano przeciwdziałać powstaniu „dominikańskich fraticellich".

Nie ulega wątpliwości, że zagadnienie dominikanów-spirytuałów znajduje się na marginesie historii zakonu XIV stulecia, a samo wywołanie tego tematu może budzić zdziwienie ${ }^{94}$. Jak bowiem wiadomo, w trakcie sławnego sporu papieża Jana XXII z franciszkańskimi spirytuałami i cesarzem Ludwikiem IV Bawarskim dominikanie zajęli wybitnie propapieskie i antycesarskie stanowisko ${ }^{95}$. Co więcej, najbliższymi doradcami papieża i współtwórcami jego polityki byli trzej generałowie zakonu: Berengariusz z Landore (1312-1317), Hervé Noël (1318-1323) i Barnaba z Vercelli (1323) ${ }^{96}$. Świadectwa tej ścisłej współpracy odnajdujemy zarówno w dokumentach papieskich, jak i tekstach prawnych zakonu. W bulli papieskiej Quia quorundam z 13 listopada 1324 r., w której uznano za herezję twierdzenie spirytuałów, że Chrystus i apostołowie nie posiadali niczego osobiście ani wspólnie, przywołany został zakon dominikański jako wzór i przykład właściwie rozumianego i praktykowanego ubóstwa ${ }^{97}$. $Z$ kolei dominikanie w trakcie kapituły generalnej w Tuluzie w 1328 r. wspomnieli o ekskomunice papieskiej nałożonej na cesarza Ludwika IV Bawarskiego i zakazali

${ }^{94}$ Temat ten dotychczas nie doczekał się dokładnego opracowania, zob. F. Ehrle, Die Spiritualen, ihr Verhältniss zum Franziskanerorden und zu den Fraticellen, „Archiv für Literatur- und Kirchengeschichte des Mittelalters" 3, 1887, s. 611-614; R. P. Mortier, Histoire des maîtres généraux, t. 2, Paris 1905, s. 556-560; W. A. Hinnebusch, Dominikanie krótki zarys dziejów, w: Dominikanie. Szkice z dziejów zakonu, red. M. A. Babraj, Poznań 1986, s. 162-163; E. Panella, Alla ricerca di Ubaldo da Lucca, „Archivum Fratrum Prædicatorum" 64, 1994, s. 39-49.

${ }^{95}$ Zob. T. Turley, Infallibilists in the curia of Pope John XXII, , Journal of Medieval History” 1, 1975, s. 71-101; B. Guillemain, Les Dominicains et la Papauté d'Avignon, „Cahier de Fanjeaux" 36, 2001, s. 307-318; U. Horst, The Dominicans and the Pope, Notre Dame, Ind. 2002, s. 23-42; T. Gałuszka, Magia jako factum hoereticale: wokół bulli Jana XXII, PH 2, 2006, s. 221-240; M. M. Mulchahey, The Dominican „Studium Romance Curice”: the Papacy, the „Magisterium" and the Friars, w: Philosophy and Theology, s. 577-600; P. Nold, How influential was John of Naples, OP at the Papal Court in Avignon, w: Philosophy and Theology, s. 629-676.

${ }_{96}$ Zob. R. P. Mortier, op. cit., t. 2, s. 475-586; t. 3, Paris 1907, s. 1-41.

${ }^{97}$ Zob.: „Prædicatores Christum pauperem imitari, ipsosque perfectionem evangelicam amplexari, et in statu exsistere perfectorum, quodque ipsorum religionis observantia perfectionis evangelicæ tenet formam; et tamen constat, ipsos habere posse etiam quoad proprietatem aliqua iuxta eorum regulam in communi", Extravagantes Ioanni, w: Corpus Iuris Canonici, t. 2, tit. 14, c. 5, kol. 1233. 
wszystkim braciom pod karą więzienia zakonnego jakichkolwiek form wspierania monarchy ${ }^{98}$. Natomiast dwa lata później kapituła generalna w Utrechcie włączyła do swoich protokołów obszerne papieskie potępienie z 1329 r. cesarza Ludwika IV Bawarskiego oraz dwóch czołowych spirytuałów - Michała Ceseny i Piotra Rainalducciego (antypapieża Mikołaja $\mathrm{V}, 1328-1330)^{99}$. Kopie tego dokumentu, zgodnie ze specjalnym nakazem generała zakonu Barnaby z Vercelli, miały znaleźć się we wszystkich prowincjach. Definitorzy kapituły zostali zobowiązani, ,że uczynią znaną, albo osobiście, albo przy pomocy odpowiednich braci, każdą rzecz dotyczącą tej sprawy, rozpowszechniając ją w czasie głoszonych publicznie kazań, by prowadzić ludzi do posłuszeństwa świętemu Kościołowi rzymskiemu i do wykazania fałszu wspomnianym heretykom i schizmatykom" ${ }^{100}$. Dodajmy, że akt potępienia papieskiego został odczytany w katedrze krakowskiej już 8 czerwca 1329 r., przy udziale licznej delegacji miejscowych wspólnot dominikańskiej i franciszkańskiej ${ }^{101}$. Niewątpliwie dominikanie w pełni zaangażowali się w pomoc papieżowi i walkę z błędami spirytuałów również we własnych szeregach. Władze zakonne tak na szczeblu prowincjalnym, jak i generalnym ostro reagowały na każde odstępstwa od doktryny lub zwyczajów Kościoła, zwłaszcza gdy rodziły podejrzenie o sympatyzowanie ze spirytuałami.

Ok. 1300 r. w prowincji rzymskiej pojawiła się grupa dominikanów, która podjęła pierwsze próby reformy. Ponieważ podkreślali konieczność odnowy życia zakonnego i radykalizm ewangeliczny, przypominali nieco grupę franciszkańskich fraticellich. Stąd też wkrótce pojawiły się oskarżenia o sprzyjanie spirytuałom. Proces wytoczono nawet samemu prowincjałowi Hugonowi Borgognoniemu, lecz kapituła generalna oczyściła go z wszelkich zarzutów ${ }^{102}$. Kolejną informację na temat grupy dominika-

${ }^{98}$ Zob. MOPH, t. 4, s. 178-179.

${ }_{99}$ Zob. ibidem, s. 201-205.

100 „Ego frater Barnabas, magister ordinis, sanctissimi patris ac domini summi pontificis mandatis in omnibus volens obedire, dicta mandata apostolica in actis presentis capituli generalis fratribus denunciare precepi atque in virtute sancte obediencie mandavi diffinitoribus prefati capituli, ut copiam illorum articulorum, prout in hac schedula continentur, ad suas provincias diligenter fideliterque deportent ac per eosdem in virtute sancte obediencie preceptum misi ad omnes et singulos priores provinciales et conventuales ac eorum vicarios, ut omnia et singula ad dictam materiam pertinencia per se vel per alios fratres ydoneos publicent in sermonibus publicis vulgarizando et ad obedienciam sancte Romane ecclesie dictorumque rebellium hereticorum et scismaticorum confutacionem populos inducendo", ibidem, s. 205.

${ }^{101}$ Zob. Monumenta Polonice Vaticana, t. 3, wyd. J. Ptaśnik, Cracoviæ 1914, s. 274-279, nr 245-247; K. Kantak, Franciszkanie w Polsce, t. 1, Kraków 1937, s. 114.

${ }_{102}$ Zob. R. P. Mortier, op. cit., t. 2, s. 556-557. W aktach kapituł generalnych brak jednak informacji na temat tego procesu. 
nów „a quibusdam spirituales vocantur” odnajdujemy w aktach kapituły rzymskiej z 1319 r. ${ }^{103}$ Najprawdopodobniej sprawę wnieśli sami oskarżeni. Podobnie jak miało to miejsce w przypadku Hugona kapituła nie tylko odsunęła od nich wszelkie podejrzenia, ale również zakazała używania nazwy spirituales w stosunku do jakiegokolwiek dominikanina ${ }^{104}$. Jednak, jak pokazują postanowienia kapituł prowincji rzymskiej z dwudziestych lat XIV w., wśród dominikanów rzeczywiście pojawili się bracia żyjący na wzór franciszkańskich spirytuałów. W 1324 r. kapituła prowincjalna w Rzymie nakazała przeorom napominać i surowo karać tych członków swoich wspólnot, u których dostrzegli „mores singulares et doctrina fratrum quorumdam qui spirituales hactenus sunt vocati"105. Powyższe zarządzenie zostało powtórzone także w 1326 r., przy czym władze prowincji zdefiniowały owych spirituales jako „rebelles et inobedientes sancte Romane ecclesie"106. W 1329 r., czyli już po ekskomunice Ludwika Bawarskiego i głównego przywódcy zbuntowanych franciszkanów Michała Ceseny, prowincjał prowincji rzymskiej, mając na względzie powagę oskarżeń o sprzyjanie spirytuałom, zarezerwował sobie rozstrzyganie spraw „dominikańskich fraticellich”107.

Sytuacja w prowincji rzymskiej nie pozostała niezauważona przez najwyższe władze zakonu. Już w 1321 r. problemem braci „qui spirituales vocantur" zajęła się kapituła generalna we Florencji. Rezultatem pracy komisji kapitulnej, w skład której wchodził generał zakonu Hervé Noël, dominikański teolog i główny doradca papieża Jana XXII Piotr z Palude ${ }^{108}$ oraz 16 definitorów ${ }^{109}$, było przygotowanie specjalnego listu generała zakonu (litterce magistri). Po uwierzytelnieniu pieczęciami wszystkich wyżej wspomnianych dominikanów dokument ten został dołączony do akt kapituły generalnej. Warto zauważyć, że w tej komisji znalazł się również

${ }^{103}$ Zob. Acta capitulorum Provincialium Provincice Romanice (1243-1344), wyd. T. Kæppeli, Romæ1941, MOPH, t. 20, s. 217-218.

${ }^{104}$ Zob.: „Ad hec insuper adicientes quod, cum istud nomen «spirituales» quamdam singularitatem videatur in nostro ordine generare, inhibemus districte sub pena gravi culpe debita ne nomine supradicto aliquis audeat fratres quoscumque singulariter nominare", ibidem, s. 218.

${ }^{105}$ Ibidem, s. 232.

106 Ibidem, s. 236.

${ }^{107}$ Ibidem, s. 250-251.

108 Zob. U. Horst, op. cit., s. 33-35.

${ }^{109}$ Kapituła w 1321 r. była kapitułą generalną definitorów, tzn. przedstawicieli braci, wybranych na kapitule prowincjalnej. Według średniowiecznego prawodawstwa dominikańskiego kapituły generalne powinny były odbywać się co roku, w następującym porządku: dwie kapituły generalne definitorów, po których była jedna kapituła prowincjałów. Zob. G.R. Galbraith, The Constitution of the Dominican Order, London 1925, s. 85-109. 
definitor polski - Stefan ${ }^{110}$. Rzeczony list generała zawierał oficjalne stanowisko zakonu wobec dominikańskich spirytuałów oraz dwa zarządzenia.W pierwszej kolejności komisja potwierdziła decyzję kapituły prowincjalnej prowincji rzymskiej z 1319 r. i jednoznacznie stwierdziła: „Non invenimus in predictis esse probatum contra eos aliquid contra fidem seu eciam bonos mores, nec eciam in eis invenimus singularitatem vite fundatam in aliqua heresi vel errore" ${ }^{111}$. Opinia ta została prawie dosłownie powtórzona w dalszej części dokumentu w formie uroczystego orzeczenia ${ }^{112}$. Następnie komisja, chcąc przeciwdziałać powstawaniu wewnątrz zakonu grup na wzór franciszkańskich spirytuałów, ogłosiła jeszcze dwa zarządzenia.Zabroniono braciom podejmowania singularitetam in modo vivendi, czyli takich form i praktyk życia zakonnego, które odbiegałyby od przyjętych zwyczajów i przepisów zakonu. W dokumencie znalazł się także wyraźny zakaz tworzenia nielegalnych organizacji. Przepis ten był skierowany do tych spośród dominikanów, którzy pod pretekstem pogłębienia życia duchowego chcieliby utworzyć nowe grupy i wspólnoty religijne ${ }^{113}$. W drugim zarządzeniu komisja przypomniała postanowienie rzymskiej kapituły prowincjalnej z 1319 r. i surowo zabroniła używania w stosunku do jakiegokolwiek dominikanina określeń sugerujących związki z herezją, np. spirituales, de spiritu, spigolistas ${ }^{114}$.

Dokument z 1321 r. nie zawierał dokładnego rodzaju sankcji,jakiej podlegali bracia łamiący przedstawione zarządzenia. Komisja pozostawiła tę kwestię do rozeznania właściwym przełożonym i zaznaczyła jedynie, że tego typu przypadki powinno być potraktowane jako poważne wykroczenie (gravis culpa).Zgodnie z przepisami prawa zakonnego popełnienie gravis culpa pociągało za sobą oprócz pokuty również kary cielesne w postaci kil-

110 Zapewne tożsamy ze Stefanem, przeorem krakowskim, poświadczonym na tym stanowisku w 1320 r., zob. Archiwum oo. Dominikanów w Krakowie, sygn. perg. 421, zob. także. M. Zdanek, Szkoły i studia, s. 63, przyp. 13.

${ }_{111} \mathrm{MOPH}, \mathrm{t} .4$, s. 137.

112 Zob.: „Determinamus omnes nemine discrepante et ex consciencia et de iure nichil esse probatum contra eos, qui spirituales vocantur, seu confessatum per eos contra fidem et bonos mores et contra singularitatem vite in aliquo errore seu secta fundatam", ibidem.

${ }^{113}$ Zob.: „Publice inhibemus et districtius, ne aliquis frater singularitatem habeat in modo vivendi, que de se induceret in scandalum vel errorem, et nullus frater singularis in oracionibus sive abstinenciis et modo vivendi quantumcumque eciam virtuoso alios pro secta et colligacione fienda ad se trahere audeat quoquomodo, et penas imponimus contrarium facientibus valde graves", ibidem.

${ }^{114}$ Zob.: „Prohibemus districte sub penis determinatis et gravibus, ne aliquis ex proposito vel deliberacione et ex certa sciencia fratrem aliquem vel aliquos in communi spirituales vel de spiritu seu eciam spigolistas vel quovis nomine significante sectam vel colliganciam singularem appellare presumat", ibidem, s.137-138. 
kudniowych postów o chlebie i wodzie ${ }^{115}$. Ale już w 1327 r. kapituła generalna w Perpignan, dostrzegając wzrost napięcia pomiędzy franciszkańskimi fraticellimi a papieżem Janem XXII, określiła nowy trójelementowy sposób postępowania wobec braci podejrzanych o kontakty czy wręcz przynależność do spirytuałów. Od tej pory oskarżony miał być w pierwszej kolejności upomniany, następnie w razie braku poprawy przeniesiony do innego konwentu, a w końcu ukarany jedną z najcięższych kar w dominikańskim systemie penitencjarnym - pobytem w więzieniu zakonnym ${ }^{116}$. Co ciekawe, kapituła w Perpignan rozszerzyła listę wykonawców tej kary. Od tej pory mogła ona być wymierzana nie tylko przez kapitułę prowincjalną, ale również przez prowincjała ${ }^{117}$. Dodajmy, że w obradach tej kapituły uczestniczyła również delegacja polskich definitorów. Wówczas polscy dominikanie sporządzili tam nowy egzemplarz Liber Constitutionum ${ }^{118}$.

Warto przytoczyć jeszcze jedno postanowienie zakonu z trzydziestych lat XIV w. Nawiązywało ono wprost do zakazów ogłoszonych przez komisję kapitulną w $1321 \mathrm{r}$. Bracia zebrani na kapitule generalnej w Londynie w $1335 \mathrm{r}$. postanowili uregulować sprawę zaangażowania dominikanów w duszpasterstwo osób świeckich. Kapituła zauważyła, że pojawiły się pewne nielegalne grupy pobożnych mężczyzn i kobiet, którzy prowadzili życie na wzór zakonników, a ich opiekunami, a nawet założycielami byli niektórzy dominikanie. Ponieważ takie wspólnoty funkcjonowały bez zgody władz Kościoła i zakonu, w konsekwencji były one podejrzane o herezję. Mając na uwadze powagę całej sprawy, „magister ordinis in virtute sancte obediencie de diffinitorum consilio" wydał bezwzględny zakaz członkom swojego zakonu jakiejkolwiek współpracy ze wspomnianymi grupami świeckich. Sankcją za złamanie tego zakazu była przede wszystkim kara więzienia zakonnego. Ponadto kapituła przewidziała nową sankcję, która nie była dotąd stosowana w dominikańskim prawie karnym przekazanie ramieniu świeckiemu ${ }^{119}$. Jak wiadomo, rozwiązanie to było

115 Zob. T. Gałuszka, Kara więzienia, s. 72.

116 Zob.: „Quicumque in nostro ordine inventi fuerint singularem vitam quocumque modo viciosam ducentes et contra communem modum vivendi diu ab ordine approbatum, primo admoneantur, et si admoniti correcti non fuerint, separentur et in diversis conventibus ponantur; et si in eodem persistant, per priorem provincialem vel provinciale capitulum carcerali custodie mancipentur", MOPH, t. 4, s. 169. Zarządzenie, które następowało po wyżej wspomnianym, informowało, że kara więzienia przewidziana jest dla braci popełniających przestępstwa, za które w prawie świeckim groziła kara śmierci (poena mortis).

117 Zob. G. R. Galbraith, op. cit., s. 83; T. Gałuszka, Kara więzienia, s. 69.

${ }^{118}$ Zob. Biblioteka Uniwersytecka we Wrocławiu, sygn. IV F 174, k. 84r-102v. Kapituła generalna w Perpignan zwolniła z urzędu prowincjała pierwszego polskiego inkwizytora - Peregryna z Opola, zob. MOPH, t. 4, s. 171; K. Kaczmarek, op.cit., s. 420, nr 73.

${ }^{119}$ Zob. „Ne ea, que sub specie religionis fiunt, ipsimet religioni pericula et scan- 
ostatnim etapem postępowania inkwizycyjnego ${ }^{120}$. Po kapitule w $1335 \mathrm{r}$. temat dominikańskich spirytuałów nie pojawił się już w aktach kolejnych kapituł generalnych. Było to spowodowane przede wszystkim wypracowaniem przez zakon szeregu narzędzi prawnych, które skutecznie przeciwdziałały powstawaniu jakichkolwiek nielegalnych ruchów wewnątrz zakonu.

$\mathrm{Na}$ koniec tej krótkiej prezentacji należy poczynić jeszcze jedną ważną uwagę. Kapituły generalne w oficjalnych tekstach zakonu z dwudziestych i trzydziestych lat XIV w. zakazywały braciom stosowania tego określenia w stosunku do jakiegokolwiek zakonnika, nawet przejawiającego tendencje spirytualistyczne. Istniało bowiem niebezpieczeństwo zbyt łatwego i niesprawiedliwego utożsamienia ich z potępionym przez Kościół ruchem franciszkańskich spirytuałów. I nawet jeżeli potocznie używano określenia „dominikański spirytuał”, to rozumiano go jako dość pojemny synonim zakonnika, który albo głosił nauki sprzeczne z doktryną Kościoła, albo podejmował praktyki dewocyjne i działania duszpasterskie bez stosownych pozwoleń. Termin ten zatem był raczej tworem retorycznym niż opisem realnie istniejącego przedstawiciela jakiegoś heterodoksyjnego ruchu. Dominikańscy spirytuałowie nigdy nie stworzyli organizacji, która na wzór franciszkańskich fraticellich posiadałaby ramy instytucjonalne oraz jeden zespół charakterystycznych dla niej poglądów. Co więcej, oni sami swoją aktywność uzasadniali potrzebą reformy życia dominikańskiego.

Powróćmy teraz do omawianego zarządzenia z $1338 \mathrm{r}$. Z perspektywy naszego studium szczególnie istotne są postanowienia dwóch kapituł generalnych z lat 1321 i 1327. Porównanie tych tekstów z aktami z 1338 r. pozwala definitywnie rozwiązać kilka z sygnalizowanych wcześniej trudności.

dala pariant, dum sine discrecionis tramite fiunt ac eciam sine suorum superiorum licencia, beneplacito, consilio et assensu, precipit magister ordinis in virtute sancte obediencie de diffinitorum consilio et assensu, quod nullus frater titulo cuiuscumque predicacionis vel peregrinacionis seu alio quolibet modo congregacionem virorum ac mulierum faciat seu factas et ad se confluentes regat vel deducat, nisi secundum modum hactenus in ordine consuetum. Si quis autem oppositum huiusmodi facere presumpserit, imponit magister ordinis sub precepto prioribus provincialibus et conventualibus et eorum vicariis, quod talibus cum omni efficacia se opponant et eos a talibus desistere compellant et eos, qui in hoc casu sibi non obedierint, carcerali custodie deputent, invocato ad hoc, si oportuerit, brachio seculari”, ibidem, s. 231.

${ }^{120}$ Inkwizycja po stwierdzeniu braku skruchy u oskarżonego wydawała oskarżonego w ręce urzędników świeckich w celu nałożenia odpowiednio surowej kary (animadversione debita puniendi). Średniowieczne ustawodawstwa świeckie przewidywało tylko jeden rodzaj sankcji w takich przypadkach - egzekucję, zob. P. Kras, Ad abolendam, s. 379-423. 
[Akta polskiej Kapituly Prowincjalnej - 1338]

[.......] singularem vitam ducentes, aut contrabonos mores agentes reperiunt, eos incarcerandi liberam habeant potestatem
[Akta Kapituły Generalnej we Florencji - 1321]
Non invenimus in predictis esse probatum contra eos aliquid contra fidem seu eciam bonos mores, nec eciam in eis invenimus singularitatem vite fundatam in aliqua heresi vel errore [- $]$
[-- ] nichil esse probatum contra eos, qui spirituales vocantur, seu confessatum per eos contra fidem et bonos mores et contra singularitatem vite in aliquo errore seu secta fundatam [- $]$
[Akta Kapituły Generalnej w Perpignan - 1327] Quicumque in nostro ordine inventi fuerint singularem vitam quocumque modo viciosam ducentes et contra communem modum vivendi diu ab ordine approbatum [- $]$ et si in eodem persistant, per priorem provincialem vel provinciale capitulum carcerali custodie mancipentur.

Powyższe zestawienie daje wystarczające podstawy, by zidentyfikować wspomnianych w zarządzeniu z 1338 r. „, singularem vitam ducentes, aut contra bonos mores agentes". Okazuje się, że byli nimi sami dominikanie. Polscy inkwizytorzy zatem zostali zobowiązani przez kapitułę prowincjalną do ścigania zakonników, których sposób życia i działalność odbiegały od zwyczajów przyjętych w zakonie. W trakcie kapituły prowincjalnej w 1338 r. polscy bracia sięgnęli przede wszystkim do akt kapituły generalnej z 1327 r. Znajomość tych tekstów nie dziwi, zważywszy na udział w obradach w Perpignan polskich definitorów. Zaczerpnięto z nich część słownictwa oraz rodzaj sankcji. Tym zaś, co stanowiło novum w zarządzeniu z 1338 r., było rozszerzenie listy osób posiadających potestatem liberam incarcerandi. Kapituła generalna z 1327 r. władzy osadzania braci w więzieniu udzieliła jedynie prowincjałowi i kapitule prowincjalnej, natomiast polscy bracia przekazali ją zakonnym inkwizytorom. Kapituła prowincjalna jednak nie zrezygnowała ze swoich prerogatyw, ale raczej rozbudowała i usprawniła system kontroli wewnątrz prowincji. Od tej pory inkwizytorzy mogli bez konieczności oczekiwania na obradującą raz w roku (a niekiedy rzadziej) kapitułę prowincjalną szybko reagować na ewentualne 
przypadki heterodoksji wśród dominikanów. Pojawienie się zarządzenia z 1338 r. możemy potraktować jako nowy etap w dziejach inkwizycji w Polsce - officium inquisitionis zostało zintegrowane z dominikańskim systemem penitencjarnym, a inkwizytorzy stali się urzędnikami prowincji, których obowiązkiem było ściganie nie tylko heretyków sensu stricto, ale również errantes w macierzystym zakonie.

Zadanie, które mieli podjąć polscy inkwizytorzy, nie było łatwe i - jak możemy się domyślać - już samo wykazanie, że jakiś brat rzeczywiście prowadził vitam singularem i działał contra bonos mores, wymagało od nich wysokich kompetencji. Dominikańscy spirytuałowie bowiem ani nie łamali obserwancji zakonnych, ani też nie grzeszyli nieobyczajnością czy jawną krytyką papiestwa. Wręcz przeciwnie, starali się żyć radykalnie i pobożnie. Ekspert zatem, który miał się podjąć rozpoznania i oceny tego typu delikatnych spraw, musiał być zarazem biegłym prawnikiem, teologiem, jak i doświadczonym zakonnikiem. Warunki te - zgodnie z ustawodawstwem kościelnym i zakonnym - spełniali właśnie dominikańscy inkwizytorzy ${ }^{121}$. Od tej zakonnej normy nie odbiegali również inkwizytorzy z polskiej prowincji: Mikołaj, Jan Schwenkenfeld i Stanisław z Krakowa. Wszyscy trzej sprawowali funkcje lektorów, przeorów, a jeden z nich, inkwizytor małopolski - Stanisław, kilka lat później (1344) został obrany miejscowym prowincjałem $^{122}$.

W świetle tych obserwacji możemy wreszcie zapytać: czy omówiona wcześniej sprawa Mikołaja Duthorowa nie była polską odpowiedzią na podnoszony przez kapituły generalne problem dominikańskich spirytuałów? Niewątpliwie, przypadek gryfijskiego dominikanina można interpretować jako ewidentny przejaw vitce singularis i działanie contra bonos mores. W swoich poglądach wykraczał on poza przyjęte przez zakon ramy dyskursu teologicznego i - co gorsza - głosił je publicznie w trakcie officium prcedicationis. Biorąc pod uwagę popularność w trzydziestych latach doktryny Mistrza Eckharta oraz Henryka Suzo, Mikołaj Duthorow z pewnością miał liczne grono słuchaczy zarówno wśród współbraci, jak i osób świeckich. Już sam fakt sympatyzowania z mistyką niemiecką rzucał cień na jego osobę. Nie sposób także wykluczyć, że wbrew postanowieniom kapituły generalnej w Londynie z 1335 r. zaangażował się on w jakąś organizację religijną, która nie posiadała licencji ze strony zakonu. Reakcja i decyzja polskiej kapituły prowincjalnej nie pozostawiają żadnych złudzeń, że tutejsi dominikanie nie akceptowali tego rodzaju poglądów i działalności. Trzeba jednak zauważyć,

${ }^{121}$ Zob. P. Kras, Działalność inkwizycyjna, s. 198-199; M. Zdanek, Inkwizytorzy dominikańscy, s. 227-228; K. Kaczmarek, Wykształcenie średniowiecznych inkwizytorów dominikańskich na ziemiach polskich, w: Inkwizycja papieska, s. 197-217.

${ }^{122}$ Zob. przyp. 80-82. 
że surowy wyrok, jaki usłyszał Mikołaj Duthorow, nie był ostatnim słowem kapituły w tej sprawie. Polscy dominikanie, biorąc pod uwagę kazus Mikołaja i realną możliwość rozszerzania się podobnych błędów wśród braci, ustanowili zakonnych inkwizytorów na straży ortodoksji w polskiej prowincji. Decyzja ta doskonale wpisywała się w zainicjowany w $1321 \mathrm{r}$. ogólnozakonny program walki z tendencjami spirytualistycznymi wśród dominikanów.

Na zakończenie tej sekcji chciałbym jeszcze postawić jeden postulat badawczy, który domaga się osobnego opracowania. Przedstawiony wyżej przypadek Mikołaja Duthorowa i dominikańskich spirytuałów zachęca do przyjrzenia się innemu zagadnieniu, mianowicie obecności franciszkańskich ruchów spirytualnych w średniowiecznej Polsce. Generalnie temat franciszkańskich spirytuałów cieszy się dużym zainteresowaniem wśród współczesnych mediewistów ${ }^{123}$. Warto jednak zaznaczyć, że historycy w przeważającej większości koncentrują się na działalności spirytuałów w Italii i południowej Francji ${ }^{124}$. Problem natomiast obecności spirytuałów

${ }^{123}$ Warto tutaj wspomnieć choćby o publikacjach dwóch historyków Davida Burra i Patricka Nolda, którzy niedawno podsumowali dotychczasowe badania na temat trzynasto- i czternastowiecznych zwolenników radykalnego ubóstwa, zob. D. Burr, Pierre de Jean Olieu: Franciscain Persécuté, Friburg 1997; idem, The Spiritual Franciscan: from protest to persecution in the century after Saint Francis, University Park, Penn. 2001; idem, The Antichrist and the Jews in Four Thirteenth-century Apocalypse Commentaries, w: Friars and Jews in the Middle Ages and Renaissance, red. S. E. Myers, S.J. McMichael, Leiden 2004, s. 23-38; idem, John XXII and the Spirituals: Is Angelo Telling the Truth?, „Franciscan Studies" 63, 2005, s. 271-287; P. Nold, Pope John XXII and his Franciscan Cardinal: Bertrand de la Tour and the Apostolic Poverty Controversy, Oxford 2007; idem, Pope John XXII's Annotations on the Franciscan Rule: Content and Contexts, „Franciscan Studies” 65, 2007, s. 295-324; idem, Two views of John XXII as a heretical pope, w: Defenders and Critics of Franciscan Life: Essays in Honor of John V. Fleming, red. M. Cusato, G. Geltner, Leiden 2009, s. 139-158; idem, Marriage advice for a pope: John XXII and the Power to Dissolve, Leiden, 2009; idem, John XXII, the Franciscans, and the Rule, w: The Cambridge Companion to St. Francis, Cambridge 2011, s. 55-69; idem, Jean XXII et Bertrand de la Tour: anatomie d'une relation, „Cahiers de Fanjeaux” 45, 2012, s. 34-56. Na gruncie historiografii polskiej na uwagę zasługują przede wszystkim starsze rozprawy Tadeusza Manteuffla i Stanisława Byliny, zob. T. Manteuffel, Narodziny herezji, Warszawa 2008, s. 109-128; S. Bylina, Wizje społeczne w herezjach średniowiecznych: humiliaci, begini, begardzi, Wrocław 1974; idem, Ruchy heretyckie w średniowieczu. Studia, Wrocław 1991. Zob. również: M. Duniluk, Fraticelli, w: Encyklopedia katolicka, t. 5, red. L. Bieńkowski, Lublin 1989, kol. 698-700; J. Łopat, Wilhelma Ockhama „Opus nonaginta dierum” jako epigońska i desperacka obrona ideału franciszkańskiego ubóstwa w XIV wieku, „Lignum Vitœ” 10, 2009, s. 11-58.

${ }^{124}$ Grupy tego typu istniały również w Grecji, Armenii, Palestynie i Syrii, zob. F. Ehrle, Die Spiritualen, ihr Verhältniss zum Franziskanerorden und zu den Fraticellen, „Archiv für Literatur- und Kirchengeschichte des Mittelalters" 4, 1888, s. 94, 163; E. Potkowski, Heretyk Stefan z Marchii, w: Polska w świecie. Szkice z dziejów kultury polskiej, red. J. Dowiat, Warszawa 1972, s. 169-178. W 2006 r. amerykańska historyczka Courtney Kneupper, pracując nad anonimowym Tractatus de beghardis, przekonująco wykazała obecność 
w średniowiecznej Polsce - według dostępnej mi wiedzy - nie pojawia się w najnowszej literaturze przedmiotu, co nie oznacza, że nie był on poruszany we wcześniejszym piśmiennictwie historycznym. Wspomnę tylko, że już w 1618 r. dominikański historiograf Abraham Bzowski powiązał powstanie polskiej inkwizycji papieskiej w 1327 r. z kontrowersjami wokół miejscowych franciszkańskich spirytuałów ${ }^{125}$. Teza Bzowskiego została bezkrytycznie przyjęta przez dziewiętnastowiecznych pisarzy, m.in. Sadoka Barącza, Melchiora Bulińskiego i Juliana Bukowskiego ${ }^{126}$. Dopiero w 1924 r. krótko odniósł się do niej Kazimierz Dobrowolski, który w swoim sławnym studium pt. Pierwsze sekty religijne w Polsce zauważył, że pogląd, jakoby w czternastowiecznej Polsce istnieli franciszkańscy fraticelli, pozbawiony jest wystarczających podstaw źródłowych ${ }^{127}$. I choć sam Dobrowolski nie odrzucił całkowicie przypuszczeń Bzowskiego, to wyrażona przez niego wątpliwość została uznana przez późniejszych historyków za definitywne rozwiązanie rzeczonego problemu. Należy jednak wyraźnie podkreślić, że temat ten wciąż oczekuje na podjęcie i weryfikację.

\section{IV}

Spróbujemy teraz podsumować najważniejsze ustalenia poczynione $\mathrm{w}$ trakcie analizy fragmentu akt polskiej kapituły prowincjalnej z $1338 \mathrm{r}$.:

1. Omawiany fragment akt z 1338 r. składa się z dwóch części: pokuty (pœnitentia) nałożonej na polskiego dominikanina Mikołaja Duthorowa i ściśle z nią związanego zarządzenia (ordinatio), które zostało skierowane do miejscowych inkwizytorów.

2. Mikołaj Duthorow zapewne był członkiem dominikańskiego konwentu w Gryfii. Tam też w trakcie działalności kaznodziejskiej głosił poglądy uznane przez współbraci za error condemnatus ab Ecclesia. W wyniku analizy teologiczno-historycznej zostało wykazane, że w doktrynie Mikołaja odnajdujemy wyraźne nawiązania do myśli i twórczości dwóch dominikanów niemieckich: Eckharta z Hochheim i Henryka Suzo. Ich działalność wywołała falę podejrzeń oraz oskarżeń o herezję, czego konsekwencją były m.in. procesy zakonne w latach 1325 i 1332 oraz potępienie papieskie z $1329 \mathrm{r}$.

w 1339 r. franciszkańskich spirytuałów w Metzu, zob. C. Kneupper, Reconsidering Fourteenth-Century Heresy Trial in Metz. Beguins and Other, „Franciscana” 8, 2006, s. 187-225.

125 Zob. A. Bzovius, Annalium ecclesiasticorum, t. 14, Coloniæ 1618, kol. 506.

${ }^{126}$ Zob. S. Barącz, Rys dziejów zakonu kaznodziejskiego w Polsce, Lwów 1861, t. 1, s. 140-141; M. Buliński, Historia kościoła Polskiego, Kraków 1874, t. 1, s. 402-403; J. Bukowski, Dzieje reformacji w Polsce, od wejścia jej do Polski aż do jej upadku, t. 1, Kraków 1883, s. 10-11.

127 Zob. K. Dobrowolski, Pierwsze sekty religijne w Polsce, „Reformacja w Polsce” 3, 1924, s. 180-181. 
Sprawę polskiego brata z 1338 r. należy rozpatrywać z tej samej perspektywy co przypadki wspomnianych dwóch mistyków nadreńskich.

3. Przypadek Mikołaja Duthorowa skłonił polską kapitułę z 1338 r. do bacznego przyjrzenia się ortodoksyjności pozostałych członków prowincji. Stąd też przekazała ona papieskim inkwizytorom władzę ścigania i osądzania braci, których sposób życia, praktyki religijne i poglądy ewidentnie odbiegały od powszechnie przyjętych zwyczajów zakonnych. Decyzja polskich dominikanów dobrze wpisywała się w promowaną w dwudziestych i trzydziestych latach XIV w. antyheretycką politykę najwyższych władz zakonu. Miała ona na celu z jednej strony obronę i umocnienie dominikańskiej uniformitas, a z drugiej strony walkę z tendencjami spirytualistycznymi wśród braci. Dominikanie-spirytuałowie nigdy jednak nie uformowali ani ruchu, ani też frakcji na wzór franciszkańskich fraticellich. Określenie to było raczej synonimem zakonnika, którego praktyki religijne lub poglądy wykraczały poza normę ustaloną przez ustawodawstwo zakonne. Takim dominikaninem-spirytuałem był również „eckhartysta” Mikołaj Duthorow.

4. Kapituła prowincjalna z 1338 r. swoją ordinatio skierowała do papieskich inkwizytorów, którymi najprawdopodobniej byli: Mikołaj, Jan Schwenkenfeld i Stanisław z Krakowa. Powierzenie im potestatem liberam incarcerandi oraz włączenie ich $\mathrm{w}$ dominikański system penitencjarny było ważnym etapem w historii inkwizycji papieskiej w Polsce. Od tej pory bowiem zakres działalności miejscowych inkwizytorów był niemal nieograniczony - mogli oni zająć się nie tylko heretykami sensu stricto, ale również errantes wewnątrz własnej prowincji.

5. Przedstawiona w niniejszym studium sprawa Mikołaja Duthorowa jest oryginalnym świadectwem reakcji polskich dominikanów na pojawiające się w pierwszej połowie XIV w. nowe nurty dewocyjne, akcentujące doświadczenie mistyczne, indywidualizm i emocjonalność człowieka.

\section{Mikołaj Duthorow and his error condemnatus ab Ecclesia. Polish Dominicans, Heresy, and New Piety Currents in the First Half of the Fourteenth Century}

The purpose of this study is to analyse a fragment of the documents of a provincial chapter of the Polish Domicans from 1338, containing a poenitentia imposed on the Polish Dominican Mikołaj Duthorow and an ordinatio addressed to local representatives of the Inquisition. Mikołaj Duthorow was probably a member of the Dominican monastery in Gryfia (German: Greifswald), where as a preacher he voiced views regarded by his co-brethren as error condemnatus ab Ecclesia. A theological-historical analysis enabled Tomasz Gałuszka to show that the doctrine proclaimed by Mikołaj contains distinct references to the thoughts and activity 
of two German Dominicans: Master Eckhart of Hochheim and Heinrich Seuse. The case of Mikołaj Duthorow inclined the Polish chapter (1338) to take a closer look at the orthodoxy of the remaining members of the province. It thus transferred to papal inquisitors the right to trace and try those brethren whose lifestyle, religious practices, and views were evidently at odds with universally accepted monastic customs. The provincial chapter from 1338 addressed its edict to papal inquisitors, probably: Mikołaj, Jan Schwenkenfeld and Stanisław of Cracow. The process of entrusting them with potestas libera incarcerandi and inclusion into the Dominican penitentiary system was an important stage in the history of the papal Inquisition in Poland. From that time, the range of the activity of local inquisitors was almost un limited - they could deal not only with heretics sensu stricto but also with errantes within the province. The case of Mikołaj Duthorow comprises original evidence of the reaction of Polish Dominicans to new devotion currents appearing in the first half of the fourteenth century and accentuating mystical experiences, individualism, and emotional life.

Translated by Aleksandra Rodzińska-Chojnowska 